\title{
2011'den Günümüze Suriyeli Göçü Bağlamında Yazın Çözümlemesi
}

\section{Literature Analysis in the Context of Syrian Immigration from 2011 to the Present}

\author{
Yeliz POLAT * \\ Zeynep TUR $\breve{G} A^{* *}$
}

$\ddot{O} Z$

Türkiye bağlamında uluslararası göç olgusu değerlendirildiğinde, Osmanlı'nın son döneminde ve cumhuriyetin ilk yıllarında Osmanlı'nın eski tebaalarından Anadolu'ya yoğun göçlerin yaşandı̆̆ı görülmektedir. Bu göç akını 1950 'lerde Arnavut 1980'lerde de Bulgaristan'dan gelen göçmenler ile devam etmiştir. Bu sürecin son halkası ise 2011 sonrası Suriye'deki halkın demokrasi mücadelesine karşı rejimin bastırma çabaları ile milyonlarca Suriyeli, Türkiye başta olmak üzere Lübnan ve Ürdün gibi ülkelere sı ğınmıştır. Türkiye’nin ev sahipliği yaptı̆̆ bu yoğun kitlesel Suriyeli göçü, ülkenin sosyal, kültürel, demografik ve ekonomik dinamiklerinde değişime neden olmuştur. Böylece sosyal, kültürel, ekonomik ve siyasal hayatta büyük yankı uyandıran Suriyeli göçü, aynı zamanda akademik çalışmalarda da etkisini göstermiştir. Bu bağlamda yazın çalışmasında, Türkiye'de uluslararası göç bağlamında ele alınan Suriyeli göçüne yönelik 2011-2021 yılları arasında yayınlanmış olan 430 makale, doküman taramasına dayalı olarak nicel ve nitel olmak üzere iki boyutlu çözümlenmiştir. Elde edilen nicel veriler, durum saptayıcı araştırma yöntemine göre, nitel veriler ise içerik çözümleme yöntemine göre irdelenmiştir. Yapılan analizler sonucu, elde edilen dokümanların en fazla eğitim, kültür, medya, ekonomi ve sağlık, en az ise kadın ve yüksekögrenim temalarında ele alındı̆̆ı tespit edilmiştir. Ayrıca, dokümanların tematik kodlamalarında en fazla "Suriyeli temel ĕgitimdeki öğrencilerin eğitim alanında karşılaştıkları sorunlar" ve "Suriyelilere yönelik tutumlar" başlığı altında ele alındıkları tespit edilmişstir.

\author{
ANAHTAR KELIMELER \\ Türkiye, Uluslararası Göç, Suriyeli Göçü, Yazın Çözümleme
}

\begin{abstract}
When the immigration phenomenon is evaluated in the context of Turkey, it is seen that there were intense immigrations from the former subjects of the Ottoman Empire to Anatolia in the last period of the Ottoman Empire and the first years of the republic. This influx of immigration continued with immigrants from Albania in the 1950s and from Bulgaria in the 1980s. In the last link of this process, after 2011, as a result of the regime's efforts to suppress the people's struggle for democracy in Syria, millions of Syrians took refuge in countries such as Lebanon and Jordan, especially Turkey. This massive Syrian immigration hosted by Turkey has caused a change in the country's social, cultural, demographic and economic dynamics. Thus, the Syrian immigration, which had great repercussions in social, cultural, economic and political life, also showed its effect in academic studies. In this context, in the literature study, 430 articles published between 2011-2021 on Syrian immigration, which was discussed in the context of international migration in Turkey, were analyzed in two dimensions as quantitative and qualitative. In the study, document scanning, one of the qualitative research designs, was used. The quantitative data obtained during the document scanning were analyzed according to the status determination research study method, and the qualitative data were analyzed according to the content analysis method. As a result of the analyzes made, it was determined that the obtained documents discussed the themes of education, culture, media, economy and health the most, and women and higher education the least. In addition, it has been determined that in the twenty-two sub-thematic coding of the documents, the topics of "problems faced by Syrian students in primary education" and "attitudes towards Syrians" are mostly discussed.
\end{abstract}

\section{KEYWORDS}

Turkey, International Migration, Syrian Immigration, Literature Analysis

\begin{tabular}{|c|c|c|}
\hline \multicolumn{2}{|r|}{$\begin{array}{l}\text { Makale Geliş Tarihi / Submission Date } \\
\text { 22.07.2021 }\end{array}$} & $\begin{array}{c}\text { Makale Kabul Tarihi / Date of Acceptance } \\
\text { 23.09.2021 }\end{array}$ \\
\hline Atıf & $\begin{array}{l}\text { Polat, Y. ve Turğa, Z. (2021). } 2011 \\
\text { Üniversitesi Sosyal Bilimler Meslek Yül }\end{array}$ & $\begin{array}{l}\text { yeli Göçü Bağlamında Yazın Çözümlemesi. Selçuk } \\
\text { 2), 400-420. }\end{array}$ \\
\hline
\end{tabular}

\footnotetext{
* Dr. Öğretim Üyesi, Fırat Üniversitesi İktisadi ve İdari Bilimler Fakültesi Kamu Yönetimi, ylzaktas@firat.edu.tr, ORCID: 0000-0002-6980-5742. ** Doktora Öğrencisi, İstanbul Medeniyet Üniversitesi Sosyal Bilimler Enstitüsü Kamu Yönetimi ABD, turgazeynep12@gmail.com, ORCID: 0000$0001-5603-6238$.
} 


\section{GİRIŞ}

İnsanoğlu, hayatı boyunca dış etmenler ve istekleri doğrultusunda sürekli bir yer değişiminde bulunmuştur. İnsanların bir yerden başka bir yere gerçekleştirmiş oldukları bu devinimi, literatürde göçün tanımı olarak geçmektedir. İnsanoğlunun yer değişikliğiyle gerçekleştirmiş olduğu bu göç serüveni hem sebep hem de sonuç bakımından farklılıklar göstermiştir. Bu yönüyle göç, konjonktürel dinamik bir yapıya sahiptir. Göç, insanoğlunun sadece fiziksel bir mekân olarak gerçekleştirdiği değişim değil aynı zamanda sosyal bir değişimi de ifade etmektedir. Göçmenler, göç sürecinde kendi kültürel değerlerini ve kimliklerini de göç edilen ülkelere taşımaktadır. Bu süreçte, göçmenler kendileriyle birlikte taşıdıkları değer yargılarını göç ettikleri kültürlerde de yaşatmaya çalışmaktadırlar.

2011 sonrası, Suriye'de meydana gelen iç karışıklar, birçok insanın ölümüne ve insanların yurtlarını terk etmesine neden olmuştur. İnsanların maruz kaldığı bu zülüm karşısında, tercih yapma imkânı kalmadan kaçabildikleri ilk yere sığınmışlardır. Suriyelilerin zulümden kaçarak sığındıkları ilk ülkelerden biri de Türkiye olmuştur. Hem coğrafi yakınlık hem de Türkiye'nin ılımlı ve hoşgörü politikasına dayanan "açık kapı" politikasından (Polat, 2017: 277) dolayı Suriyeliler tarafından Türkiye, sığınılacak ilk ülke olmuştur. Göç İdaresi Genel Müdürlügü’nün 2021 yılı Haziran verilerine göre, 3.675.485 Suriyeli Türkiye'de yaşamaktadır (www.goc.gov.tr, 2021). Türkiye'nin ev sahipliği yaptığı bu kitlesel göç, sosyo-kültürel ve ekonomik olarak önemli toplumsal etkilere neden olmaktadır. Kentleşmenin \%80'lerin üzerinde olduğu Türkiye'de, kent alanlarında özellikle de kayıtlı il nüfusuna göre daha yoğun Suriyeli nüfusunu barındıran Kilis, Hatay, Gaziantep, Şanlıurfa, Mersin, Adana, Mardin gibi (www.goc.gov.tr, 2021) şehirlerde Suriyeli göçü daha yoğun etki yaratmaktadır. Türkiye'deki hem beşeri hem de sosyal bilimleri etkileyen Suriyeli göçü, akademik çalışmalarda da yerini almıştır. Yazın çalışmalarında, Suriyeli göçüne yönelik Türkiye'nin göç politikası, göçlerin sebebiyet verdiği göç sorunsalı ve göç sorununa yönelik çözüm önerileri ele alınmıştır. Araştırmada, Suriyeli göçünün yazın çalışmalarındaki konumu tespit edilerek, Türkiye'deki Suriyeli göç sorunsalının tespiti ve önemi ile henüz hiç ya da yeteri derecede sorunsallaştırılmamış konuların ortaya çıkarılması amaçlanmıştır. $\mathrm{Bu}$ amaç doğrultusunda, Türkiye'de Suriyeli göçü bağlamında ele alınan 430 makale ele alınarak derinlemesine analiz edilmiştir.

\section{ARAŞTIRMA YÖNTEMI}

$\mathrm{Bu}$ araştırmada, nitel araştırma desenlerinden doküman taramasından yararlanılmıştır. Doküman taraması, araştırmacının ulaşmak istediği olgu ve olaylar hakkında bilgi veren ve kanıt niteliği taşıyan yazılı ve yazısız materyallerin analizidir. Doküman taraması başta sosyal bilimciler olmak üzere birçok farklı bilim dallarında destekleyici veri ve ana veri olarak kullanılmaktadır. Sosyal bilimcilerin ulaşmayı hedeflediği olgu ve olaylar, birtakım kanıt ve keşiflerle ortaya çıkmaktadır. Bu bağlamda, araştırmacının ulaşmayı hedeflediği olgu ve olaylar hakkındaki kanıtları araştırma konusu hakkında bilgi içeren dokümanlar oluşturmaktadır. Araştırmacı, ulaşmayı hedeflediği amaçların güvenirliliğini arttırmak için doküman taraması yaparken birtakım araştırma aşamalarına dikkat etmesi gerekmektedir. Doküman taraması; dokümanları elde etme, dokümanlarının orijinalliğini tespit etme, dokümanlarını kavrama, verileri çözümleme ve elde edilen verilerden yararlanma olmak üzere beş aşamadan oluşmaktadır (Forster'dan aktaran Yıldırım ve Şimşek, 2011: 193). Bu bağlamda, araştırma da Suriye göçünü ele alan 430 makale, yazın taramasına dayalı olarak çözümlenmiş ve Suriyeli göçünün literatürdeki niceliksel ve niteliksel boyutları incelenmiştir. Bu çerçevede, öncelikle Suriyeli göçüne ilişskin yazın çalışmalarının tespiti için, "TR Dizin", "DergiPark" ve "Academia" dergi listelerinde; uluslararası göç ve Suriyeliler başlıkları altında taranarak 2011-2021 yılları arasında üretilen makalelere ulaşılmıştır. Ulaşılan 430 makaleden elde edilen veriler, öncelikle tarihsel sürece göre konu sınıflandırılmasına tabi tutulmuştur. Ardından, makaleler; sosyal, kültürel, ekonomik, hukuki, sağlık, küreselleşme, siyasi, yönetimsel ve kavramsal sınıflandırmalara tabi tutularak özel olarak incelenmiştir.

Doküman taramasının dördüncü aşaması olan, verilerin çözümleme evresinde ise elde edilen yazın çalışmaları nicel ve nitel olmak üzere iki yönteme dayalı olarak çözümlenmiştir. Araştırmada, elde edilen dokümanların nicel analizinde, nicel araştırma analiz yöntemlerinden durum saptayıcı araştırma yönteminden yararlanılmıştır. Durum saptayıcı, evrende ulaşılması amaçlanan karakteristik olguların hangi aralıklarla ele alındığının tespiti yapılarak bu verilerin sayısal dökümünü ortaya koyan araştırma yöntemidir (Sencer ve Irmak, 1984: 25). Araştırmanın nitel çözümlenmesinde ise veri analiz yöntemlerinden içerik çözümleme yöntemi kullanılmıştır. İçerik analiz yöntemi, herhangi bir yazın çalışmasında yer alan temaları, kavramları, karakter ve nesneleri ortaya koyarak sayısal çıkarımında bulunma işlemidir. Literatürde, içerik analiz yöntemi nitel argümanların nicel olarak ifade edilme yöntemi olarak kullanılsa da aslında içerik analiz yöntemi özünde nitel araştırmaya dayanmaktadır (Kızıltepe, 2017: 253-262). İncelenen yazın çalışmaları sonucu, içerik analiz yöntemine dayalı olarak Suriyeli göçüne ilişkin Uluslararası Suriyeli Göçü, Suriyeliler, Suriyeli Sorunu, 
Çocuk, Aile, Eğitim, Din, Medya, Sanat, Kadın, Kentleşme, Kültür, Ekonomi, Sosyal Hizmetler ve STK'lar, Yönetim, Siyasa ve Yerel Yönetimler, Güvenlik, Diplomasi, Hukuk, Vatandaşlık, Sağlık, Kurumsal 22 alt tema ve bu temaları temsil eden kod oluşturulmuştur. 430 makale çözümlenmiş fakat bazı makalelerin birden fazla tematik alana girmesi nedeni ile aynı anda farklı iki temada yer bulmuştur. Bu nedenle Tablo 8'deki toplam sayı 450 olarak verilmiştir. Araştırma, Türkiye'de Türkçe ve yabancı dilde yayın yapan dergiler ile sınırlandırılmıştır.

\section{SURIYELİ GÖÇÜ BAĞLAMINDA ALAN YAZIN ÇÖZÜMLEMESI}

2011 sonrası Suriyeli göçüyle birlikte uluslararası göç, Türkiye için önemli bir sorunsal ve gündemi meşgul eden önemli bir çalışma alanı olmuştur. Ülke genelinde büyük bir önem arz eden bu alan, akademik çalışmalarda da kendini göstermiştir. Uluslararası göç alanında ele alınan yazın çalışmalarında önemle durulan Suriyeli göçü, Suriyelilerin kalıcı olmasıyla birlikte gittikçe üzerinde yoğunlaşılan ve yazın çalışmalarının ana temasını oluşturan önemli bir sorunsaldır. İlgili yazın çalışmasında da uluslararası göç ve Suriye göçünü konu edinen 430 yazın çalışması ele alınarak hem nicel hem de nitel bağlamda çözümlenmiştir.

\subsection{Suriyeli Göçü Alan Yazınının Nicel Çözümü}

Suriyeli göçü alan yazının nicel çözümlenmesinde öncelikle tarihsel olarak 2012'den günümüze yapılan çalışmaların sayısındaki değişim tespit edilmiştir. Ardından çalışmaların ana sorunsalları tespit edilerek sosyal, kültürel, sağlık, ekonomik, yönetsel, siyasal vb. başlıklar altında yazın çalışmalarının konu dağılımı ele alınmıştır. Ardından yazın çalışmalarının araştırma yöntemleri tespit edilerek çalışmalar yazın çalışmalarının yayımlandığı dergiler, yazın çalışmalarının örneklem dağılımı, yazın çalışmalar nitel, nicel ve karma olarak sınıflandırılmıştır. Ardından çalışmaların saha araştırma bölgeleri tespit edilerek en çok hangi mekânsal örgütlenmelerin sorunsallaştıııldığı tespit edilmiş̧tir. Son olarak da çalışmalardaki Suriyelilere yönelik tanımlamalar belirlenerek sınıflandırılmıştır.

\section{Şekil 1. Yazın Çalışmalarının Tarihsel Dağılımı}

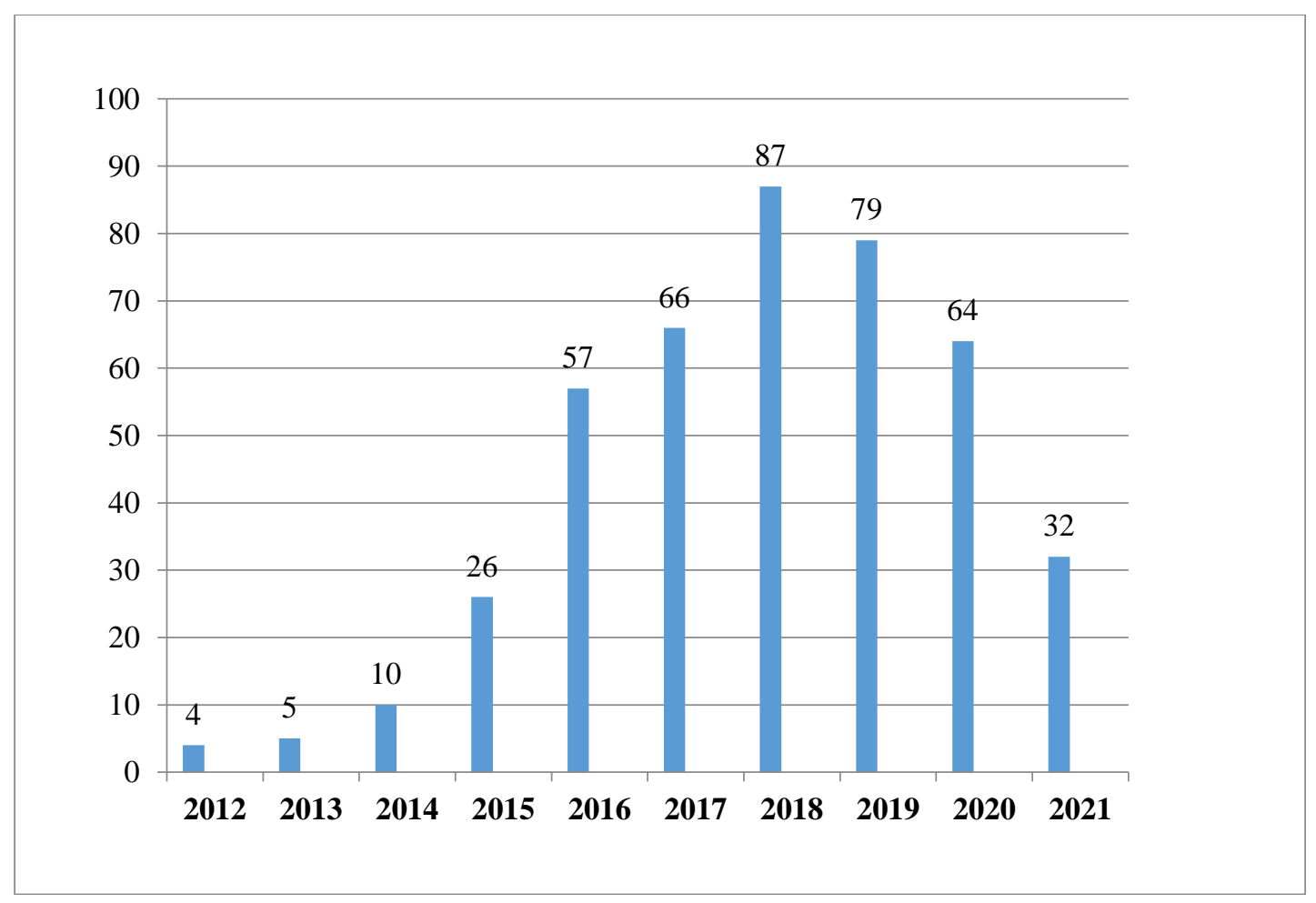




\section{Şekil 2. Yıllara Göre Geçici Koruma Altındaki Suriyeliler}

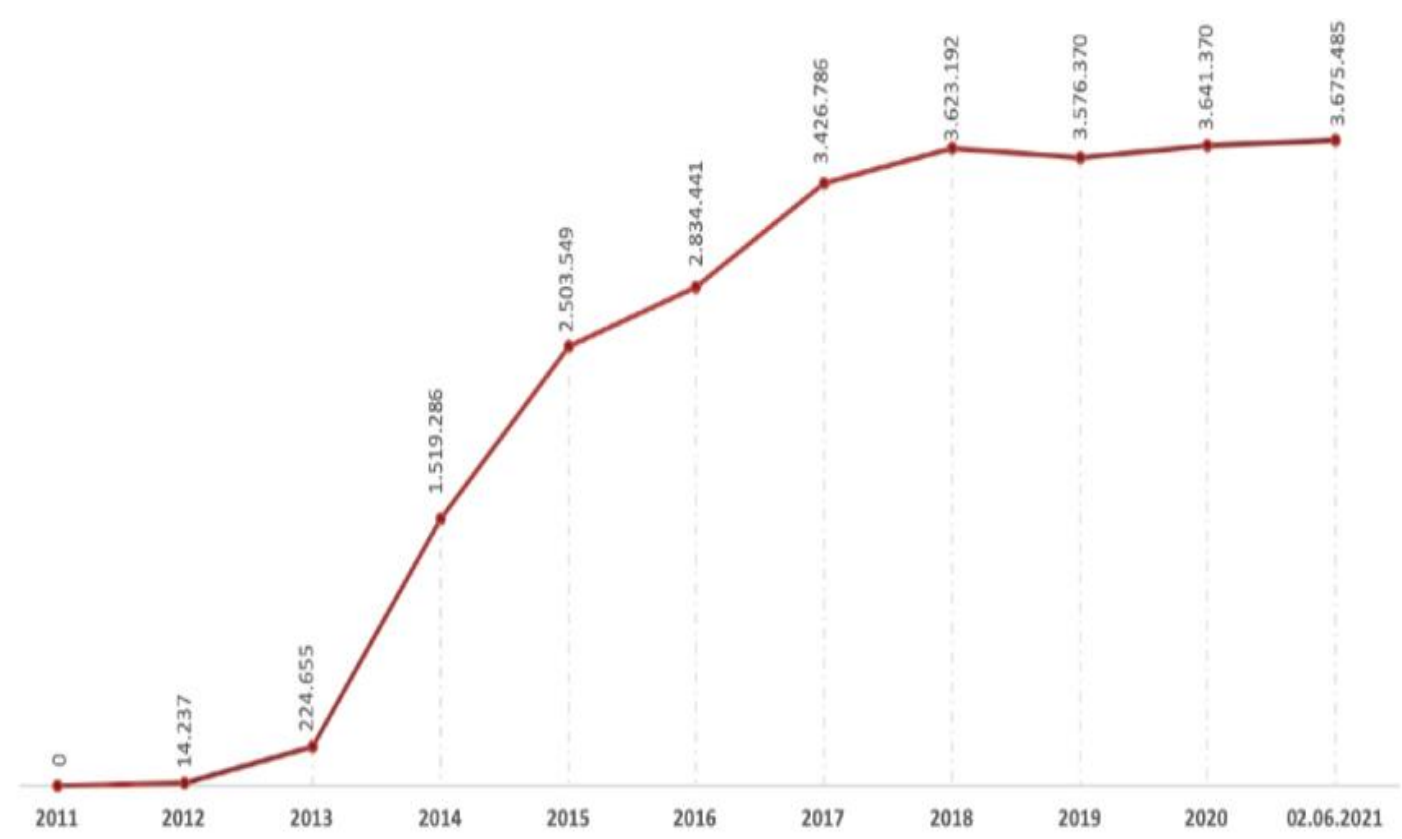

Kaynak: (www.goc.gov.tr, 2021)

Türkiye'deki Suriyeli sayısındaki artışa paralel olarak 2012 yılı sonrası Suriyeli göçü üzerine kaleme alınan yazın çalışmalarında, niceliksel olarak artış yaşanmıştır. Özellikle, 2015 yılından 2018 yılına kadar Suriyelilere yönelik yazın çalışmalarında ciddi artışların yaşandığı tespit edilmiştir. 2019 yılında Suriyeli göçmen sayısında yaşanan görece azalış yayına da yansımış ve yayın sayısı 79'a gerilemiştir. Bu gerileme 2020 yılında da devam etmiştir. Fakat 2021 yılının ilk 4 ayındaki yayın sayısı 32 olmuştur. Yani 2021 yılı itibariyle yayın sayısının daha da artacağı bu konuya olan akademik ilginin devam edeceği ifade edilebilir.

İncelenen yazın çalışmaları sonucu, Suriyelilere yönelik en erken tarihli yazın çalışmalarının 2012 yılında kaleme alındığı tespit edilmiştir. Ayrıca, bu dönemde ele alınan yazın çalışmalarının hukuki bağlamda ele alındığı tespit edilmiştir. Bu dönemde hukuki bağlamda ele alınan örnek çalışmalardan biri de Poyraz (2012) tarafından kaleme alınan yazın çalışmasıdır. İlgili yazın çalışmasında, uluslararası ve ulusal yasal düzenlemeler çerçevesinde Suriyelilerin hukuki statüsü incelenmiştir. İlerleyen yıllarda, Suriyelilerin kalıcı olmasıyla birlikte Suriyelilere yönelik ele alınan yazın çalışmalarında da artışlar yaşanmıştır. Suriyelileri konu alan yazın çalışmalarının en fazla 2018 ve 2019 yıllarında kaleme alındığı tespit edilmiştir.

Şekil 3. Yazın Çalışmalarının Konu Dağglımı

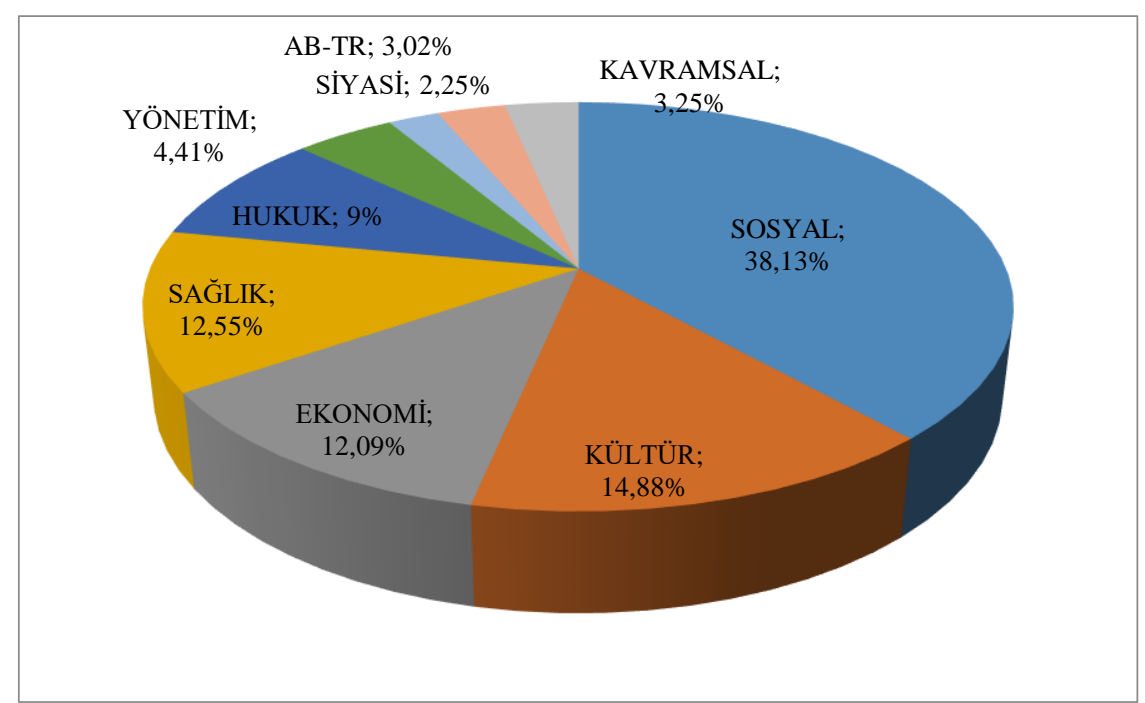

Yukarıdaki grafikte, ele alınan yazın çalışmalarının konu dağılımına yer verilmiştir. İlgili grafik incelendiğinde, ele alınan 430 makalenin en fazla sosyal boyutta ( $f=164)$ ele alındığı görülmektedir. Sosyal boyutta ele alınan çalışmaların alt başlıklarında ise daha çok çocukların eğitim hayatı, medya, Suriye göçünün 
Türkiye'ye genel etkileri ve Suriyelilerin yaşamış oldukları sorunlar yer almaktadır. Ayrıca, eğitim alanında ele alınan yazın çalışmalarının çoğunluklu olarak ilkokul, ortaokul ve lise düzeyindeki öğrenciler bağlamında ele alındıkları ancak yükseköğrenim gören öğrencilere yönelik yazın çalışmalarının yeteri düzeyde ele alınmadıkları tespit edilmiştir. İncelenen yazın çalışmalarında; ana okul, ilkokul, ortaokul ve lise düzeyindeki öğrencileri konu alan toplam 65 yazın çalışması tespit edilmiştir. Yükseköğrenim gören Suriyeli öğrencilere yönelik ise 12 yazın çalışmasının ele alındığı tespit edilmiştir. Sosyal boyuttan sonra üzerinde en fazla çalışmanın yer aldığı diğer bir alan ise kültürdür $(\mathrm{f}=64)$. Kültürel bağlamda ele alınan yazın çalışmalarının alt başlıkları ise daha çok Suriyelilerin entegrasyon süreçleri ve dışlanma olgusudur. Ayrıca, kültürel bağlamda ele alınan yazın çalışmalarında yerel halk ve Suriyeliler arasındaki algı ve tutum düzeylerini konu alan yazın çalışmalarının örnekleminin çoğunluğunu, üniversite öğrencilerinin oluşturduğu tespit edilmiştir. Sosyal ve kültürel boyuttan sonra üzerinde en fazla çalışmanın yer aldığ 1 alanlar sağlık $(f=54)$, ekonomi ( $f=52)$, ve hukuktur ( $\mathrm{f}=39$ ). Ekonomi alanında ele alınan çalışmalar, daha çok Suriyeli göçünün Türkiye'ye ekonomik etkileri ve Suriyelilerin çalışma sorunları üzerine kaleme alınmıştır. Sağlık boyutunda ele alınan çalışmalar ise daha çok Suriyelilerin savaş yaralanmaları ve kadın sağlığı üzerine kaleme alınmıştır. Hukuki alanda ise mülteci hukuku, yabancılar ve koruma kanunu ve geçici koruma rejimi üzerine çalışmalar sıklıkla yer almaktadır. Suriye göçüne yönelik ele alınan çalışmalarda konu dağılımı bakımından en az çalışmanın ise siyasi alanda ( $\mathrm{f}=11$ ) ele alındığı tespit edilmiştir. Siyasi alanda ele alınan yazın çalışmaları ise genellikle yerel yönetimler ve sivil toplum kuruluşlarını içermektedir. Diğer ele alınan yazın çalışmalarının dağılımı: Türkiye'deki göç örgütlenmesi çerçevesinde "Yönetim" ( $\mathrm{f}=19)$, Suriyeli göçü ve uluslararası göçün teorik çerçeveden ele alındığı "Kavramsal" ( $\mathrm{f}=14)$ ve Avrupa Birliği ile Türkiye arasındaki ilişkiler bağlamında "ABTR" (f=13)'dir.

\section{Tablo 1. Yazın Çalışmalarında Araştırma Yöntemleri}

\begin{tabular}{|llc|}
\hline Nicel Araştırma & \multicolumn{1}{c|}{ ARAŞTIRMA YÖNTEMLERI } \\
\hline Karma Araştırma & & $\mathbf{\% 1 2 , 7 9}(\mathbf{f}=\mathbf{5 5})$ \\
\hline & & $\mathbf{\% 4 , 1 8}(\mathbf{f}=\mathbf{1 9})$ \\
\hline \multirow{3}{*}{ Nitel Araştırma } & Literatür Derleme & $\% 59,55(\mathrm{f}=212)$ \\
\cline { 2 - 3 } & Saha Araştırması & $\% 39,60(\mathrm{f}=141)$ \\
\cline { 2 - 3 } & Literatür Çözümleme & $\% 0,84(\mathrm{f}=3)$ \\
\cline { 2 - 3 } & Toplam & $\mathbf{\% 2 , 7 9}(\mathbf{f}=\mathbf{3 5 6})$ \\
\hline
\end{tabular}

İncelenen yazın çalışmalarında; nicel araştırma $(\mathrm{f}=55)$, karma araştırma $(\mathrm{f}=19)$ ve nitel araştırma $(\mathrm{f}=356)$ olmak üzere üç farklı araştırma yönteminin kullanıldığ 1 ve araştırma yöntemlerinden en fazla "nitel araştırma yöntem"inden yararlanıldığı tespit edilmiştir. Ayrıca, nitel araştırma yönteminin kullanıldığı yazın çalışmaları da "literatür derleme, saha araştırması ve literatür çözümleme" olmak üzere üç kategoride sinıflandırılmıştır. Bu kategoride de yazın çalışmalarının çoğunluklu olarak literatür derlemesi bağlamında ele alındıkları tespit edilmiştir.

Tablo 2. Yazın Çalışmalarının Yayınlandığı Sosyal Bilimler Dergi Listesi

\begin{tabular}{|c|c|c|c|c|c|c|c|}
\hline \multicolumn{8}{|c|}{ SOSYAL BILIMER DERGISI } \\
\hline ACSES Dergisi & 1 & $\begin{array}{l}\text { Çankırı Karatekin } \\
\text { Üniversitesi SBE } \\
\text { Dergisi }\end{array}$ & 1 & $\begin{array}{l}\text { İletişim Çalışmaları } \\
\text { Dergisi }\end{array}$ & 5 & $\begin{array}{l}\text { Sosyal Bilimler } \\
\text { Araştırmaları Dergisi }\end{array}$ & 2 \\
\hline $\begin{array}{l}\text { Adam Akademi Sosyal } \\
\text { Bilimler Dergisi }\end{array}$ & 1 & $\begin{array}{l}\text { Çocuk ve Medeniyet } \\
\text { Dergisi }\end{array}$ & 1 & İlköğretim Online & 1 & $\begin{array}{l}\text { Sosyal Çalışmalar } \\
\text { Üzerine Akademik } \\
\text { Perspektif Dergisi }\end{array}$ & 2 \\
\hline $\begin{array}{l}\text { Adıyaman Üniversitesi } \\
\text { SBE Dergisi }\end{array}$ & 2 & $\begin{array}{l}\text { Çocuk, Edebiyat ve } \\
\text { Dil Eğitimi Dergisi }\end{array}$ & 1 & $\begin{array}{l}\text { İnönü Üniversitesi } \\
\text { Eğitim Fakültesi } \\
\text { Dergisi }\end{array}$ & $\mathbf{1}$ & $\begin{array}{l}\text { Sosyal Çalışma } \\
\text { Dergisi }\end{array}$ & 1 \\
\hline $\begin{array}{l}\text { Afyon Kocatepe } \\
\text { Üniversitesi Sosyal } \\
\text { Bilimler Dergisi }\end{array}$ & $\mathbf{1}$ & $\begin{array}{l}\text { Çukurova Eğitim } \\
\text { Fakültesi Dergisi }\end{array}$ & 1 & $\begin{array}{l}\text { İnönü Üniversitesi } \\
\text { Hukuk Fakültesi } \\
\text { Dergisi }\end{array}$ & $\mathbf{1}$ & $\begin{array}{l}\text { Sosyal Ekonomik } \\
\text { Araştırmalar Dergisi }\end{array}$ & 2 \\
\hline $\begin{array}{l}\text { AHBVÜ Turizm } \\
\text { Fakültesi Dergisi }\end{array}$ & 1 & $\begin{array}{l}\text { Çukurova İlahiyat } \\
\text { Dergisi }\end{array}$ & 1 & $\begin{array}{l}\text { İnsan ve Toplum } \\
\text { Bilimleri } \\
\text { Araştırmaları Dergisi }\end{array}$ & 3 & $\begin{array}{l}\text { Sosyal Güvenlik } \\
\text { Dergisi }\end{array}$ & 1 \\
\hline
\end{tabular}




\begin{tabular}{|c|c|c|c|c|c|c|c|}
\hline Ahi Evran İIBF Dergisi & 2 & Darulfunün Dergisi & 1 & $\begin{array}{l}\text { International Journal } \\
\text { of Georaphy and } \\
\text { Georaphy Education }\end{array}$ & 2 & $\begin{array}{l}\text { Sosyal Güvence } \\
\text { Dergisi }\end{array}$ & 1 \\
\hline $\begin{array}{l}\text { Ahi Evran Üniversitesi } \\
\text { SBE Dergisi }\end{array}$ & 1 & $\begin{array}{l}\text { Dicle Üniversitesi } \\
\text { İİBF Dergisi }\end{array}$ & 1 & $\begin{array}{l}\text { İstanbul Medipol } \\
\text { Üniversitesi Hukuk } \\
\text { Fakültesi Dergisi }\end{array}$ & 1 & $\begin{array}{l}\text { Sosyal Politika } \\
\text { Çalışmaları Dergisi }\end{array}$ & 10 \\
\hline $\begin{array}{l}\text { Akademik Bakış } \\
\text { Dergisi }\end{array}$ & 3 & $\begin{array}{l}\text { Dini Araştırmalar } \\
\text { Dergisi }\end{array}$ & 1 & $\begin{array}{l}\text { İstanbul Hukuk } \\
\text { Mecmuası }\end{array}$ & $\mathbf{1}$ & $\begin{array}{l}\text { Sosyal Siyaset } \\
\text { Konferansları Dergisi }\end{array}$ & 4 \\
\hline $\begin{array}{l}\text { Akademik } \\
\text { Hassasiyetler Dergisi }\end{array}$ & 1 & $\begin{array}{l}\text { Doğu Anadolu } \\
\text { Sosyal Bilimlerde } \\
\text { Eğilimler Dergisi }\end{array}$ & 2 & $\begin{array}{l}\text { İstanbul Ticaret } \\
\text { Üniversitesi SBE } \\
\text { Dergisi }\end{array}$ & $\mathbf{1}$ & $\begin{array}{l}\text { Sosyal ve Kültürel } \\
\text { Araştırmalar Dergisi }\end{array}$ & 2 \\
\hline $\begin{array}{l}\text { Akademik Yaklaşımlar } \\
\text { Dergisi }\end{array}$ & 1 & $\begin{array}{l}\text { Doğu Coğrafya } \\
\text { Dergisi }\end{array}$ & 1 & İstem Dergisi & 1 & $\begin{array}{l}\text { Sosyoekonomi } \\
\text { Dergisi }\end{array}$ & 2 \\
\hline $\begin{array}{l}\text { Akdeniz Eğitim } \\
\text { Araştırmaları Dergisi }\end{array}$ & 2 & $\begin{array}{l}\text { Dokuz Eylül } \\
\text { Üniversitesi SBE } \\
\text { Dergisi }\end{array}$ & 1 & $\begin{array}{l}\text { İş, Güç Endüstri } \\
\text { İlişkileri ve İnsan } \\
\text { Kaynakları }\end{array}$ & 2 & $\begin{array}{l}\text { Sosyoloji } \\
\text { Araştırmaları Dergisi }\end{array}$ & 3 \\
\hline $\begin{array}{l}\text { Akdeniz İletişim } \\
\text { Dergisi }\end{array}$ & 1 & Ege Eğitim Dergisi & 1 & İş ve Hayat Dergisi & 4 & $\begin{array}{l}\text { Sosyolojik Düzen } \\
\text { Dergisi }\end{array}$ & 1 \\
\hline $\begin{array}{l}\text { Aksaray Üniversitesi } \\
\text { İIBF Dergisi }\end{array}$ & 1 & $\begin{array}{l}\text { Eğitimde Kuram ve } \\
\text { Uygulama }\end{array}$ & 1 & $\begin{array}{l}\text { Journal of Economy } \\
\text { Culture and Society }\end{array}$ & 2 & $\begin{array}{l}\text { Spor Bilimleri } \\
\text { Araştırma Dergisi }\end{array}$ & 1 \\
\hline $\begin{array}{l}\text { Alanya Akademik } \\
\text { Bakış Dergisi }\end{array}$ & 1 & $\begin{array}{l}\text { Eğitimde Nitel } \\
\text { Araştırmalar Dergisi }\end{array}$ & 1 & $\begin{array}{l}\text { Journal of Economic } \\
\text { Development and } \\
\text { Social Research }\end{array}$ & 1 & $\begin{array}{l}\text { Süleyman Demirel } \\
\text { Üniversitesi Hukuk } \\
\text { Fakültesi Dergisi }\end{array}$ & 1 \\
\hline $\begin{array}{l}\text { Alternatif Politika } \\
\text { Dergisi }\end{array}$ & 2 & $\begin{array}{l}\text { Ekonomi, Politika ve } \\
\text { Finans Dergisi }\end{array}$ & 1 & $\begin{array}{l}\text { Journal of Innovative } \\
\text { Research in Social } \\
\text { Studies }\end{array}$ & 1 & $\begin{array}{l}\text { Süleyman Demirel } \\
\text { Üniversitesi İIBF } \\
\text { Dergisi }\end{array}$ & 4 \\
\hline Anadili Eğitim Dergisi & 3 & $\begin{array}{l}\text { Elektronik Sosyal } \\
\text { Bilimler Dergisi }\end{array}$ & 1 & $\begin{array}{l}\text { Journal of Socialand } \\
\text { Humanities Sciences }\end{array}$ & 2 & $\begin{array}{l}\text { Tesam Akademi } \\
\text { Dergisi }\end{array}$ & 5 \\
\hline $\begin{array}{l}\text { Anadolu Strateji } \\
\text { Dergisi }\end{array}$ & 1 & $\begin{array}{l}\text { Elemantary } \\
\text { Education }\end{array}$ & 1 & $\begin{array}{l}\text { Journal of } \\
\text { Humanities and } \\
\text { Tourism Research }\end{array}$ & $\mathbf{1}$ & $\begin{array}{l}\text { The Global a Journal } \\
\text { of Policy and } \\
\text { Strategy }\end{array}$ & 1 \\
\hline $\begin{array}{l}\text { Anadolu Üniversitesi } \\
\text { İletişim Bilimleri } \\
\text { Fakültesi Uluslararası } \\
\text { Hakemli Dergi }\end{array}$ & 1 & Eskiyeni Dergisi & 1 & $\begin{array}{l}\text { Journal of Tourisim } \\
\text { and Gastronomy } \\
\text { Studies }\end{array}$ & 1 & $\begin{array}{l}\text { The Journal Social } \\
\text { Science }\end{array}$ & 1 \\
\hline $\begin{array}{l}\text { Anadolu Journal of } \\
\text { Educational Sciences } \\
\text { International }\end{array}$ & 1 & $\begin{array}{l}\text { E-Şarkiyat İlmi } \\
\text { Araştırmalar Dergisi }\end{array}$ & 1 & $\begin{array}{l}\text { Journal of World of } \\
\text { Turks }\end{array}$ & 1 & $\begin{array}{l}\text { The Journal of } \\
\text { International Lingual } \\
\text { Social and } \\
\text { Educational Sciences }\end{array}$ & 2 \\
\hline $\begin{array}{l}\text { Anemon Muş } \\
\text { Alparslan Üniversitesi } \\
\text { Sosyal Bilimler Dergisi }\end{array}$ & 1 & $\begin{array}{l}\text { Euarsian Journal of } \\
\text { Educational Research }\end{array}$ & 2 & $\begin{array}{l}\text { Kahramanmaraş } \\
\text { Sütçü İmam } \\
\text { Üniversitesi İİBF } \\
\text { Dergisi }\end{array}$ & 2 & $\begin{array}{l}\text { Tihek Akademik } \\
\text { Dergisi }\end{array}$ & 1 \\
\hline $\begin{array}{l}\text { Ankara Avrupa } \\
\text { Çalışmaları Dergisi }\end{array}$ & 1 & Etkileşim Dergisi & 1 & $\begin{array}{l}\text { Kahramanmaraş } \\
\text { Sütçü İmam } \\
\text { Üniversitesi Sosyal } \\
\text { Bilimler Dergisi }\end{array}$ & 1 & $\begin{array}{l}\text { Toplum ve Sosyal } \\
\text { Hizmet }\end{array}$ & 3 \\
\hline Ankara Barosu Dergisi & 2 & $\begin{array}{l}\text { Family Practice and } \\
\text { Palliative Care }\end{array}$ & 1 & $\begin{array}{l}\text { Kafkas Üniversitesi } \\
\text { İlâhiyat Fakültesi } \\
\text { Dergisi }\end{array}$ & 1 & $\begin{array}{l}\text { TURAN-SAM } \\
\text { Uluslararası Bilimsel } \\
\text { Hakemli Dergisi }\end{array}$ & 1 \\
\hline $\begin{array}{l}\text { Ankara Hacı Bayram } \\
\text { Veli Hukuk Fakültesi } \\
\text { Dergisi }\end{array}$ & 1 & FE Dergisi & 1 & $\begin{array}{l}\text { Kilis } 7 \text { Aralık } \\
\text { Üniversitesi Sosyal } \\
\text { Bilimler Dergisi }\end{array}$ & 1 & $\begin{array}{l}\text { Turkish Journal of } \\
\text { Education }\end{array}$ & 1 \\
\hline $\begin{array}{l}\text { Ankara Üniversitesi } \\
\text { Hukuk Fakültesi } \\
\text { Dergisi }\end{array}$ & 4 & $\begin{array}{l}\text { Firat Üniversitesi } \\
\text { Sosyal Bilimler } \\
\text { Dergisi }\end{array}$ & 2 & KHO Bilim Dergisi & 1 & Turkish Studies, & 6 \\
\hline $\begin{array}{l}\text { Ankara Üniversitesi } \\
\text { SBE Dergisi }\end{array}$ & 1 & Fiscaoeconomia & 1 & $\begin{array}{l}\text { Kirıkkale } \\
\text { Üniversitesi İIBF } \\
\text { Dergisi }\end{array}$ & 1 & $\begin{array}{l}\text { Türkiye İnsan Hakları } \\
\text { ve Eşitlik Kurumu }\end{array}$ & 1 \\
\hline
\end{tabular}




\begin{tabular}{|c|c|c|c|c|c|c|c|}
\hline Asia Minor Studies & 1 & $\begin{array}{l}\text { FSM İlmi } \\
\text { Araştırmalar İnsan ve } \\
\text { Toplum Bilimleri } \\
\text { Dergisi }\end{array}$ & 1 & $\begin{array}{l}\text { Kırıkkale } \\
\text { Üniversitesi Sosyal } \\
\text { Bilimler Dergisi }\end{array}$ & 1 & $\begin{array}{l}\text { Türkiye Siyaset } \\
\text { Bilimi Dergisi }\end{array}$ & 1 \\
\hline $\begin{array}{l}\text { ASSAM Uluslararas1 } \\
\text { Hakemli Dergi }\end{array}$ & 1 & $\begin{array}{l}\text { Galatasaray } \\
\text { Üniversitesi İletişim } \\
\text { Dergisi }\end{array}$ & 1 & $\begin{array}{l}\text { KMÜ Sosyal ve } \\
\text { Ekonomik } \\
\text { Araştırmalar Dergisi }\end{array}$ & 1 & $\begin{array}{l}\text { Türkiye Sosyal } \\
\text { Araştırmalar Dergisi }\end{array}$ & 3 \\
\hline $\begin{array}{l}\text { Atatürk Üniversitesi } \\
\text { Beden Eğitimi ve Spor } \\
\text { Bilimleri Dergisi }\end{array}$ & 1 & $\begin{array}{l}\text { Gazi Üniversitesi } \\
\text { Hukuk Fakültesi } \\
\text { Dergisi }\end{array}$ & 2 & KSÜ İ̈BF Dergisi & 1 & $\begin{array}{l}\text { Türk Sosyal Bilimler } \\
\text { Araştırmaları Dergisi }\end{array}$ & 1 \\
\hline $\begin{array}{l}\text { Atatürk Üniversitesi } \\
\text { İ̈BF Dergisi }\end{array}$ & 2 & $\begin{array}{l}\text { Gaziantep } \\
\text { Üniversitesi } \\
\text { Araştırmaları Dergisi }\end{array}$ & 1 & $\begin{array}{l}\text { Kültür ve İletişim } \\
\text { Dergisi }\end{array}$ & 3 & $\begin{array}{l}\text { Türkiye Sosyal } \\
\text { Hizmet Araştırmaları } \\
\text { Dergisi }\end{array}$ & 1 \\
\hline $\begin{array}{l}\text { Atatürk Üniversitesi } \\
\text { SBE Dergisi }\end{array}$ & 1 & $\begin{array}{l}\text { Gaziantep } \\
\text { Üniversitesi Eğitim } \\
\text { Bilimleri Dergisi }\end{array}$ & 1 & $\begin{array}{l}\text { Küresel İktisat ve } \\
\text { İşletme Çalışmaları } \\
\text { Dergisi }\end{array}$ & 1 & Türkiyat Mecmuası & 1 \\
\hline $\begin{array}{l}\text { Avrasya İncelemeleri } \\
\text { Dergisi }\end{array}$ & 2 & $\begin{array}{l}\text { Gaziantep } \\
\text { Üniversitesi Journal } \\
\text { of Social Science }\end{array}$ & 1 & Legal Hukuk Dergisi & 1 & $\begin{array}{l}\text { Türkiye İletişim } \\
\text { Araştırmaları Dergisi }\end{array}$ & 2 \\
\hline $\begin{array}{l}\text { Avrasya Sosyal ve } \\
\text { Ekonomi Araştırmaları } \\
\text { Dergisi }\end{array}$ & 1 & $\begin{array}{l}\text { Gaziantep } \\
\text { Üniversitesi Sosyal } \\
\text { Bilimler Dergisi }\end{array}$ & 2 & $\begin{array}{l}\text { Liberal Düşünce } \\
\text { Dergisi }\end{array}$ & 4 & $\begin{array}{l}\text { Trakya Üniversitesi } \\
\text { İktisadi ve İdari } \\
\text { Bilimler Fakültesi } \\
\text { E-Dergi }\end{array}$ & 1 \\
\hline $\begin{array}{l}\text { Avrasya Uluslararas1 } \\
\text { Araştırmalar Dergisi }\end{array}$ & 3 & $\begin{array}{l}\text { Giresun Üniversitesi } \\
\text { İIBF Dergisi }\end{array}$ & 1 & $\begin{array}{l}\text { Marmara Coğrafya } \\
\text { Dergisi }\end{array}$ & 2 & $\begin{array}{l}\text { Uluslararası } \\
\text { Afro-Avrasya } \\
\text { Araştırmaları Dergisi }\end{array}$ & 3 \\
\hline $\begin{array}{l}\text { Aydın Adnan } \\
\text { Menderes Üniversitesi } \\
\text { SBE Dergisi }\end{array}$ & 1 & $\begin{array}{l}\text { Global Journal of } \\
\text { Economics and } \\
\text { Business Studies }\end{array}$ & 1 & $\begin{array}{l}\text { Marmara İletişim } \\
\text { Dergisi }\end{array}$ & 1 & $\begin{array}{l}\text { Uluslararasi Anadolu } \\
\text { Sosyal Bilimler } \\
\text { Dergisi }\end{array}$ & 1 \\
\hline $\begin{array}{l}\text { Balıkkesir Üniversitesi } \\
\text { SBE Dergisi }\end{array}$ & 1 & $\begin{array}{l}\text { Göç Araş̧ırmaları } \\
\text { Dergisi }\end{array}$ & 14 & $\begin{array}{l}\text { Manas Sosyal } \\
\text { Araştırmalar Dergisi }\end{array}$ & 2 & $\begin{array}{l}\text { Uluslararası İnsan } \\
\text { Çalışmaları Dergisi }\end{array}$ & 2 \\
\hline $\begin{array}{l}\text { Balkan Sosyal Bilimler } \\
\text { Dergisi }\end{array}$ & 2 & Göç Dergisi & 9 & Marife Dergisi & 2 & $\begin{array}{l}\text { Uluslararası Beşeri ve } \\
\text { Sosyal Bilimler } \\
\text { İnceleme Dergisi }\end{array}$ & 2 \\
\hline $\begin{array}{l}\text { Balkan ve Yakın Doğu } \\
\text { Sosyal Bilimler Dergisi }\end{array}$ & 1 & $\begin{array}{l}\text { Güvenlik Bilimleri } \\
\text { Dergisi }\end{array}$ & 2 & $\begin{array}{l}\text { Marmara Coğrafya } \\
\text { Dergisi }\end{array}$ & 2 & $\begin{array}{l}\text { Uluslararası Eğitim } \\
\text { Araştırmacıları } \\
\text { Dergisi }\end{array}$ & 3 \\
\hline $\begin{array}{l}\text { Batman Üniversitesi } \\
\text { Yaşam Bilimleri } \\
\text { Dergisi }\end{array}$ & 1 & $\begin{array}{l}\text { Güvenlik Çalışmaları } \\
\text { Dergisi }\end{array}$ & $\mathbf{1}$ & $\begin{array}{l}\text { Marmara Üniversitesi } \\
\text { İ̈BF Dergisi }\end{array}$ & 1 & $\begin{array}{l}\text { Uluslararası } \\
\text { Ekonomik } \\
\text { Araştırmalar } \\
\text { Dergisi } \\
\end{array}$ & 1 \\
\hline $\begin{array}{l}\text { Bilecik Şeyh Edebali } \\
\text { Üniversitesi SBE } \\
\text { Dergisi }\end{array}$ & 1 & $\begin{array}{l}\text { Güvenlik Stratejileri } \\
\text { Dergisi }\end{array}$ & 3 & $\begin{array}{l}\text { Marmara İletişim } \\
\text { Dergisi }\end{array}$ & 1 & $\begin{array}{l}\text { Uluslararas1 } \\
\text { İktisadi ve İdari } \\
\text { Bilimler Dergisi }\end{array}$ & 1 \\
\hline Bilimname Dergisi & 3 & $\begin{array}{l}\text { Haccettepe } \\
\text { Üniversitesi İIBF } \\
\text { Dergisi }\end{array}$ & 1 & $\begin{array}{l}\text { M. Akif Ersoy } \\
\text { Üniversitesi SBE } \\
\text { Dergisi }\end{array}$ & 1 & $\begin{array}{l}\text { Uluslararası } \\
\text { Karamanoğlu } \\
\text { Mehmet Bey } \\
\text { Eğitim } \\
\text { Araştırmaları } \\
\text { Dergisi } \\
\end{array}$ & 1 \\
\hline $\begin{array}{l}\text { Bilimsel Eğitim } \\
\text { Araştırmaları Dergisi }\end{array}$ & 1 & $\begin{array}{l}\text { Hacettepe } \\
\text { Üniversitesi İletişim } \\
\text { Fakültesi Kültürel } \\
\text { Çalışmalar Dergisi }\end{array}$ & 1 & Mülkiye Dergisi & 1 & $\begin{array}{l}\text { Uluslararası Kriz ve } \\
\text { Siyaset } \\
\text { Araştırmaları } \\
\text { Dergisi }\end{array}$ & 1 \\
\hline Bilgi Dergisi & 3 & $\begin{array}{l}\text { Hacettepe } \\
\text { Üniversitesi Yabancı } \\
\text { Dil Olarak Türkçe } \\
\text { Araştırmaları Dergisi }\end{array}$ & 1 & $\begin{array}{l}\text { Necmettin Erbakan } \\
\text { Üniversitesi Hukuk } \\
\text { Fakültesi Dergisi }\end{array}$ & 1 & $\begin{array}{l}\text { Uluslararası } \\
\text { Mülteci Hakları } \\
\text { Derneği }\end{array}$ & 3 \\
\hline
\end{tabular}




\begin{tabular}{|c|c|c|c|c|c|c|c|}
\hline $\begin{array}{l}\text { Bilgi ve İletişim } \\
\text { Dergisi }\end{array}$ & 2 & $\begin{array}{l}\text { HAK-İŞ Uluslararası } \\
\text { Emek ve Toplum } \\
\text { Dergisi }\end{array}$ & 1 & Nitel Sosyal Bilimler & 1 & $\begin{array}{l}\text { Uluslararası Politik } \\
\text { Araştırmalar } \\
\text { Dergisi, }\end{array}$ & 1 \\
\hline $\begin{array}{l}\text { Birey ve Toplum } \\
\text { Dergisi }\end{array}$ & 15 & $\begin{array}{l}\text { Hastane Öncesi } \\
\text { Dergisi }\end{array}$ & $\mathbf{1}$ & $\begin{array}{l}\text { Ombudsman } \\
\text { Akademi }\end{array}$ & 1 & $\begin{array}{l}\text { Uluslararası Siyaset } \\
\text { Bilimi ve Kentsel } \\
\text { Araştırmalar } \\
\text { Dergisi }\end{array}$ & 1 \\
\hline $\begin{array}{l}\text { Bitlis Eren Üniversitesi } \\
\text { Sosyal Bilimler } \\
\text { Enstitüsü Dergisi }\end{array}$ & 1 & $\begin{array}{l}\text { Harran Education } \\
\text { Journal }\end{array}$ & $\mathbf{1}$ & $\begin{array}{l}\text { Ondokuz Mayıs } \\
\text { İlahiyat Fakültesi } \\
\text { Dergisi }\end{array}$ & 1 & $\begin{array}{l}\text { Uluslararası Sosyal } \\
\text { Araştırmalar } \\
\text { Dergisi }\end{array}$ & 4 \\
\hline $\begin{array}{l}\text { Bolu Abant İzzet } \\
\text { Baysal Üniversitesi } \\
\text { Eğitim Fakültesi } \\
\text { Dergisi }\end{array}$ & 2 & $\begin{array}{l}\text { Harran Üniversitesi } \\
\text { İ̈BF Dergisi }\end{array}$ & $\mathbf{1}$ & Ortadoğu Etütleri & 2 & $\begin{array}{l}\text { Uluslararası Topum } \\
\text { Araştırmaları } \\
\text { Dergisi }\end{array}$ & 11 \\
\hline $\begin{array}{l}\text { CBÜ Sosyal Bilimler } \\
\text { Dergisi }\end{array}$ & 3 & $\begin{array}{l}\text { Hitit Üniversitesi } \\
\text { SBE Dergisi }\end{array}$ & $\mathbf{1}$ & $\begin{array}{l}\text { Pamukkale } \\
\text { Üniversitesi Eğitim } \\
\text { Fakültesi Dergisi }\end{array}$ & 1 & $\begin{array}{l}\text { Yedi Tepe } \\
\text { Üniversitesi Hukuk } \\
\text { Fakültesi Dergisi }\end{array}$ & $\mathbf{1}$ \\
\hline $\begin{array}{l}\text { ÇOMÜ Uluslararası } \\
\text { Sosyal Bilimler Dergisi }\end{array}$ & 1 & Humanitas & $\mathbf{1}$ & $\begin{array}{l}\text { Pamukkale } \\
\text { Üniversitesi SBE } \\
\text { Dergisi }\end{array}$ & 1 & $\begin{array}{l}\text { Yıldız Sosyal } \\
\text { Bilimler Enstitüsü } \\
\text { Dergisi }\end{array}$ & 1 \\
\hline $\begin{array}{l}\text { Celal Bayar } \\
\text { Üniversitesi Sosyal } \\
\text { Bilimler Dergisi }\end{array}$ & 2 & İdeal Kent Dergisi & 3 & $\begin{array}{l}\text { Paradoks Ekonomi } \\
\text { Sosyoloji ve Politika } \\
\text { Dergisi }\end{array}$ & 1 & Yönetim Bilimleri & 2 \\
\hline $\begin{array}{l}\text { Coğrafi Bilimler } \\
\text { Dergisi }\end{array}$ & 1 & $\begin{array}{l}\text { İktisadi İdari ve } \\
\text { Siyasal Araştırmalar } \\
\text { Dergisi }\end{array}$ & 1 & $\begin{array}{l}\text { PESA Uluslararası } \\
\text { Sosyal Araştırmalar } \\
\text { Dergisi }\end{array}$ & 2 & $\begin{array}{l}\text { Yönetim ve } \\
\text { Ekonomi }\end{array}$ & 1 \\
\hline $\begin{array}{l}\text { Çukurova Üniversitesi } \\
\text { SBE Dergisi }\end{array}$ & $\mathbf{1}$ & $\begin{array}{l}\text { İktisat ve Sosyal } \\
\text { Bilimlerde Güncel } \\
\text { Araştırmalar Dergisi }\end{array}$ & 2 & Perspektif Dergisi & 1 & $\begin{array}{l}\text { Yüzüncü Y1l } \\
\text { Üniversitesi } \\
\text { SBE Dergisi }\end{array}$ & 2 \\
\hline $\begin{array}{l}\text { Çalışma İlişkileri } \\
\text { Dergisi }\end{array}$ & $\mathbf{1}$ & İlahiyat Akademi & 3 & $\begin{array}{l}\text { SDÜ Fen Edebiyat } \\
\text { Sosyal Bilimler } \\
\text { Dergisi }\end{array}$ & 1 & $\begin{array}{l}\text { 21. Yüzyılda } \\
\text { Eğitim ve Toplum } \\
\text { Dergisi }\end{array}$ & 1 \\
\hline $\begin{array}{l}\text { Çalışma ve Toplum } \\
\text { Dergisi }\end{array}$ & 2 & $\begin{array}{l}\text { Ankara Üniversitesi } \\
\text { İLEF Dergisi }\end{array}$ & 1 & TOPLAM & & & 370 \\
\hline
\end{tabular}

Tablo 2 incelendiğinde, sosyal bilimler alanında yazın çalışmalarının en fazla Birey ve Toplum (f=15), Göç Araştırmaları ( $\mathrm{f}=14)$, Uluslararası Toplum Araştırmaları $(\mathrm{f}=11)$ ve Sosyal Politika Çalışmaları Dergisinde $(\mathrm{f}=10)$ yayımlandığı görülmektedir.

Tablo 3. Yazın Çalışmalarının Yayınlandığı Sağlık ve Fen Bilimleri Dergi Listesi

\begin{tabular}{|c|c|c|c|c|c|}
\hline \multicolumn{6}{|c|}{ SAĞLIK VE FEN BILIMLERI DERGISI } \\
\hline Ahi Evran Medical Journal & 1 & $\begin{array}{l}\text { Fiziksel Tip ve Rehabilitasyon } \\
\text { Bilimleri Dergisi }\end{array}$ & 2 & Pamukkale Tip Dergisi & 1 \\
\hline Ahi Evran Tip Dergisi & 1 & $\begin{array}{l}\text { Gümüşhane Üniversitesi } \\
\text { Sağlık Bilimleri Dergisi }\end{array}$ & 2 & Sağlık ve Toplum Dergisi & 3 \\
\hline $\begin{array}{l}\text { Anadolu Hemşirelik ve Sağlık } \\
\text { Bilimleri Dergisi }\end{array}$ & 1 & Harran Tip Dergisi & 1 & Sağlık ve Yönetim Dergisi & 2 \\
\hline $\begin{array}{l}\text { Archives of Health Science } \\
\text { and Research }\end{array}$ & 1 & $\begin{array}{l}\text { İnönü Üniversitesi Sağlık } \\
\text { Hizmetleri Meslek Yüksek } \\
\text { Okulu Dergisi }\end{array}$ & 1 & Sağlık Yönetimi ve Liderlik & 1 \\
\hline Aydın Sağlık Dergisi & 1 & İstanbul Tıp Dergisi & 1 & Sakarya Tıp Dergisi & 1 \\
\hline Bozok Tip Dergisi & 1 & $\begin{array}{l}\text { Jinekoloji-Obstetrik ve } \\
\text { Neonatoloji Tıp Dergisi }\end{array}$ & 1 & $\begin{array}{l}\text { Samsun Sağlık Bilimleri } \\
\text { Dergisi }\end{array}$ & 1 \\
\hline Bakırköy Tıp Dergisi & 1 & $\begin{array}{l}\text { Journal of Contemporary } \\
\text { Medicine }\end{array}$ & 2 & STED & 8 \\
\hline $\begin{array}{l}\text { Çocuk Acil ve Yoğun Bakım } \\
\text { Dergisi }\end{array}$ & 2 & Kafkas Tıp Bilimleri Dergisi & 1 & Tibbi Sosyal Hizmet Dergisi & 2 \\
\hline Çukurova Medical Journal & 1 & $\begin{array}{l}\text { Kırıkkale Üniversitesi Tıp } \\
\text { Fakültesi Dergisi }\end{array}$ & 1 & $\begin{array}{l}\text { Türkiye Klinikleri Diş } \\
\text { Hekimliği Bilimleri Dergisi }\end{array}$ & 1 \\
\hline
\end{tabular}




\begin{tabular}{|c|c|c|c|c|c|}
\hline DEUHFED & 2 & $\begin{array}{l}\text { Kocaeli Üniversitesi Sağlık } \\
\text { Bilimleri Dergisi }\end{array}$ & $\mathbf{1}$ & $\begin{array}{l}\text { Türkiye Klinikleri } \\
\text { Hemşirelik Bilimleri Dergisi }\end{array}$ & 1 \\
\hline Damar Cerrahi Dergisi & 1 & $\begin{array}{l}\text { Manisa Celal Bayar Sağlık } \\
\text { Bilimleri Dergisi }\end{array}$ & $\mathbf{1}$ & $\begin{array}{l}\text { Türkiye Klinikleri Tıp Etiği- } \\
\text { Hukuku Tarihi Dergisi }\end{array}$ & 2 \\
\hline Dicle Tıp Dergisi & 1 & $\begin{array}{l}\text { Mersin Üniversitesi Sağlık } \\
\text { Bilimleri Dergisi }\end{array}$ & 1 & Türkiye Parazitoloji Dergisi & 1 \\
\hline $\begin{array}{l}\text { Dokuz Eylül Üniversitesi } \\
\text { Hemşirelik Fakültesi } \\
\text { Elektronik Dergi }\end{array}$ & 1 & $\begin{array}{l}\text { Mimarlık Planlama ve } \\
\text { Tasarım Dergisi }\end{array}$ & $\mathbf{1}$ & $\begin{array}{l}\text { Ulus Travma Acil Cerrahi } \\
\text { Dergisi, }\end{array}$ & 3 \\
\hline $\begin{array}{l}\text { Düzce Üniversitesi Sağlık } \\
\text { Bilimleri Dergisi }\end{array}$ & 1 & Nesne Psikolojisi Dergisi & 1 & TOPLAM & 60 \\
\hline
\end{tabular}

Tablo 3 incelendiğinde, sağlık ve fen bilimleri alanında yazın çalışmalarının en fazla STED (Sürekli Tıp Eğitim Dergisi), Sağlık ve Toplum Dergisi ve Ulus Travma Acil Cerrahi Dergilerinde yayınlandığ görülmektedir.

Tablo 2 ve 3 birlikte değerlendirildiğinde görülmektedir ki en fazla yazına katkı 370 makale ile sosyal bilimler, ardından 60 makale ile sağlık bilimleri alanında sağlanmıştır.

Tablo 4. Yazın Çalışmalarının Örnek Dağılımı

\begin{tabular}{|llll|}
\hline & ÖRNEKLEM & & \\
\hline Suriyeliler & $\mathbf{1 1 3}$ & Film ve sinema & $\mathbf{3}$ \\
\hline Suriyeli ögrenciler & $\mathbf{3 1}$ & Diğer yöneticiler & $\mathbf{3}$ \\
\hline Medya & $\mathbf{2 8}$ & Literatür & $\mathbf{3}$ \\
\hline Suriyeli çocuklar & $\mathbf{2 4}$ & Okul yöneticileri & $\mathbf{3}$ \\
\hline Yerli öretmenler & $\mathbf{2 3}$ & Materyal & $\mathbf{3}$ \\
\hline Suriyeli kadınlar & $\mathbf{1 8}$ & Konutlar & $\mathbf{3}$ \\
\hline Yerel halk & $\mathbf{1 8}$ & Siyasal örgütlenmeler & $\mathbf{3}$ \\
\hline Yükseköğrenim gören Suriyeli öğrenciler & $\mathbf{1 2}$ & Suriyeli ergenler & $\mathbf{3}$ \\
\hline Yükseköğrenim gören yerel öğrenciler & $\mathbf{1 0}$ & Yerel çocuklar & $\mathbf{2}$ \\
\hline Sivil toplum kuruluşları & $\mathbf{7}$ & Oyunlar & $\mathbf{2}$ \\
\hline Yerel öğrenciler & $\mathbf{6}$ & Resimler & $\mathbf{1}$ \\
\hline Romanlar & $\mathbf{6}$ & Suriyeli müzisyenler & $\mathbf{1}$ \\
\hline Sağlık çalışanları & $\mathbf{5}$ & Suriyeli doktorlar & $\mathbf{1}$ \\
\hline Yerel yönetimler & $\mathbf{4}$ & Yemek & $\mathbf{1}$ \\
\hline GEM'lerde eğitim veren öğretmenler & $\mathbf{4}$ & Diğerleri & $\mathbf{8 5}$ \\
\hline Yerel kadınlar & $\mathbf{4}$ & & \\
\hline
\end{tabular}

Yukarıdaki tabloda, yazın çalışmalarının örneklem dağılımına yer verilmiştir. İncelenen yazın çalışmalarında, örneklem olarak en fazla Suriyeli bireylerin $(\mathrm{f}=113)$ ele alındığı tespit edilmiştir. Suriyeli bireylerden sonra en fazla örneklem olarak ele alınan Suriyeli öğrenciler ( $\mathrm{f}=31)$ ve medyadır $(\mathrm{f}=28)$. Medya bağlamında, genellikle gazete ve haber başlıklarının ele alındığı, eğitim alanında ise daha çok ilkokul ve ortaokul seviyesindeki öğrencilerin örneklem olarak kullanıldığı tespit edilmiştir. Eğitim alanında, lise ve yükseköğrenim gören öğrenciler üzerine çalışmalar daha az ele alınmıştır. İncelenen yazın çalışmalarında, özel olarak Suriyeli kadınlar ve yükseköğrenim gören Suriyeli öğrenciler bağlamında ele alan yazın çalışmalarının sınırlı olduğu tespit edilmiştir. Suriyeli kadınları ele alan çalışmaların ise daha çok sağlık alanında ele alındıkları tespit edilmiştir. Ayrıca, incelenen yazın çalışmalarında Suriyelilerin sosyal kimliklerine dayalı olarak özel çalışmaların da yer aldığı tespit edilmiştir. Bu çalışmalardan biri de Hajj (2016) tarafından kaleme alınan Suriyeli müzisyenlerin kimlik inşası ve Suriyeli müzik kültürünün ele alındığı yazın çalışmasıdır. Sanat alanında ele alınan çalışmalar; film, sinema, müzik, resim ve kitap alanında ele alındıkları ve örneklem olarak ise en fazla romanların ele alındığ kitapları ve Türkçe ders öğretiminde kullanılan materyallerdir. Konut bağlamında ele alınan yazın çalışmalarında, örneklem olarak geçici barınma merkezleri ve sosyal politika aracı olarak yetimhanelerin ele 
alındığı tespit edilmiştir. Ayrıca, incelenen yazın çalışmalarında kültürel bir olgu olarak Suriyeli yemeklerinin de örneklem olarak ele alındığ 1 tespit edilmiştir. Akbaba ve Özel (2020) tarafından kaleme alınan çalışmada, Suriyeli göçünün Kilis mutfağındaki kültürel etki düzeyi ele alınmıştır. İncelenen yazın çalışma sonucunda, yerel halkın kendi kültürel mutfağını ön plana çıkartmakla birlikte, Suriyeli göçüne bağlı olarak az da olsa Suriyeli mutfak kültüründen de etkilendikleri tespit edilmiştir.

\section{Şekil 4. Yazın Çalışmalarında Kullanılan Sosyal Medya Örneklemleri}

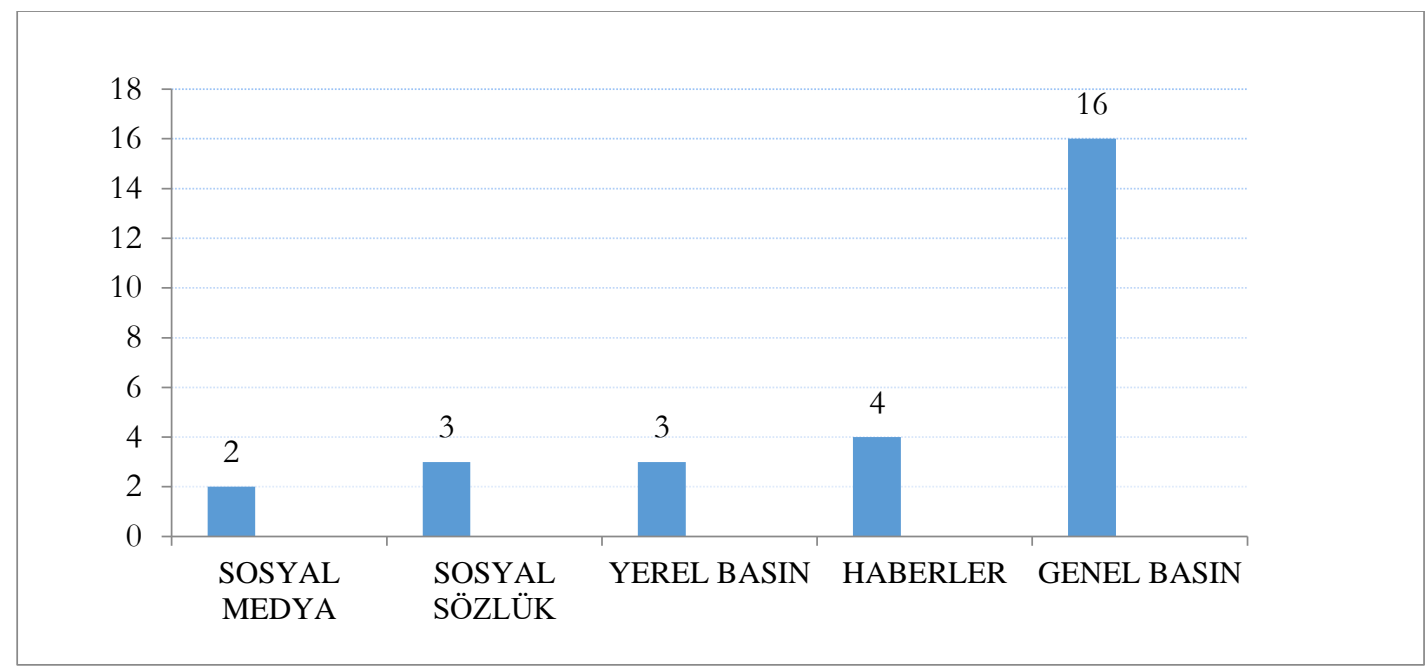

Yukarıdaki grafikte, Suriyelileri konu edinen yazın çalışmalarının örneklem olarak kullandıkları medya araçları yer almaktadır. Yukarıdaki grafik incelendiğinde, en fazla örneklemin genel basın ( $\mathrm{f}=16)$ yani gazete başlıklarının yer aldığı en az örneklemin ise sosyal medya $(\mathrm{f}=2)$ araçlarının kullanıldığı görülmektedir. Suriyelileri konu edinen yazın çalışmalarında örneklem olarak kullanılan haber kanalları; Show TV, Kanal D, Kanal 7 ve Halk TV'dir. Suriyelileri konu edinen yazın çalışmalarında kullanılan sosyal sözlükler; Ekşi Sözlük, İnci Sözlük, İTU Sözlük ve Uludağ Sözlük. Suriyelileri konu edinen yazın çalışmalarında kullanılan sosyal medya araçları ise Youtube ve Twitter'dır. Suriyelileri konu edinen yazın çalışmalarında kullanılan yerel basınlar; Kocaeli, Malatya ve Eskişehir yerel basınıdır. Suriyelilerin konu edinen yazın çalışmalarında en fazla örneklem olarak kullanılan gazeteler ise Hürriyet, Sabah ve Milliyet gazeteleridir.

\section{Şekil 5. Yazın Çalışmalarında Örneklem Olarak Yer Alan Öğretmenlerin Branş Dağılımı}

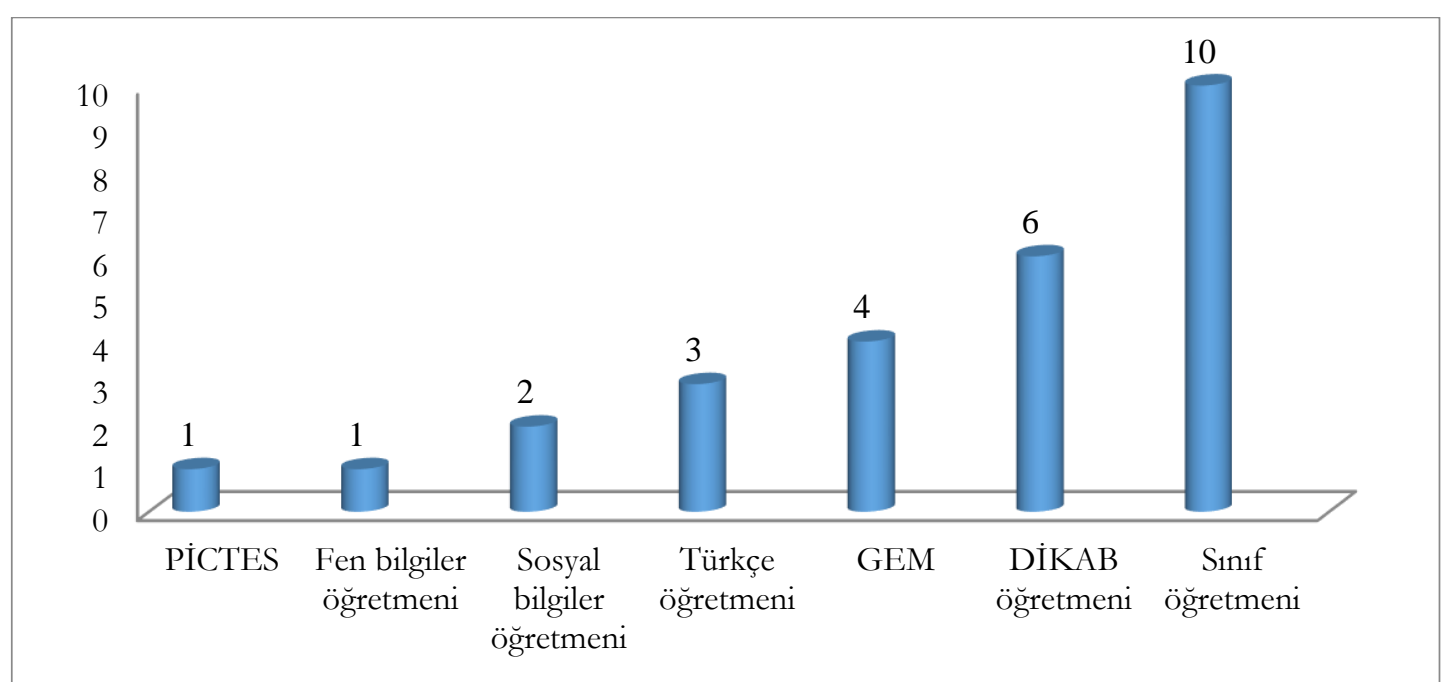

Yukarıdaki grafikte, incelenen yazın çalışmalarında, örneklem olarak yer alan öğretmenlerin branş dağılımına yer verilmiştir. İncelenen yazın çalışmalarında, örneklem olarak en fazla sınıf öğretmenleri ve DİKAB (Din Kültürü ve Ahlak Bilgisi) öğretmenlerinin yer aldığı tespit edilmiştir. 
Tablo 5. Yazın Çalışmalarının Araştırma Sahaları

\begin{tabular}{|lcllllll|}
\hline & & \multicolumn{1}{c|}{ ARAȘTIRMA SAHALARI } & & \\
\hline İstanbul & $\mathbf{2 9}$ & Kahramanmaraş & $\mathbf{8}$ & Batman & $\mathbf{2}$ & Aydın & $\mathbf{1}$ \\
\hline Kilis & $\mathbf{2 4}$ & Konya & $\mathbf{6}$ & Elazı̆ & $\mathbf{2}$ & Çanakkale & $\mathbf{1}$ \\
\hline Gaziantep & $\mathbf{2 1}$ & Kayseri & $\mathbf{5}$ & Kocaeli & $\mathbf{2}$ & Denizli & $\mathbf{1}$ \\
\hline Şanlıurfa & $\mathbf{1 7}$ & Bursa & $\mathbf{5}$ & Malatya & $\mathbf{2}$ & Erzurum & $\mathbf{1}$ \\
\hline Ankara & $\mathbf{1 3}$ & Adıyaman & $\mathbf{5}$ & Nevşehir & $\mathbf{2}$ & Muğla & $\mathbf{1}$ \\
\hline Mardin & $\mathbf{1 3}$ & Adana & $\mathbf{4}$ & Sakarya & $\mathbf{2}$ & Ordu & $\mathbf{1}$ \\
\hline Hatay & $\mathbf{1 2}$ & Kirşehir & $\mathbf{4}$ & Trabzon & $\mathbf{2}$ & Van & $\mathbf{1}$ \\
\hline Mersin & $\mathbf{9}$ & Osmaniye & $\mathbf{3}$ & Yozgat & $\mathbf{2}$ & Zonguldak \\
\hline İzmir & $\mathbf{8}$ & Eskişehir & $\mathbf{3}$ & Alanya & $\mathbf{1}$ & Ürdün & $\mathbf{1}$ \\
\hline
\end{tabular}

Yukarıdaki tabloda, Suriyelileri konu edinen yazın çalışmalarında saha araştırmalarında kullanılan yerler verilmiştir. Türkiye sınırları içerisinde toplam 35 ilde saha araştırması yapıldığı ve Türkiye sınırları dışında ise 1 bölgenin (Ürdün) saha araştırmasında kullanıldığı tespit edilmiştir. Aydın (2018) tarafından kaleme alınan yazın çalışmasında, Suriyeli göçüne bağlı olarak Ürdün'de yaşanan su sorunu ele alınmıştır.

Tablo 6. Suriyeli Nüfus Yoğunluğunun En Yüksek Olduğu İller

\begin{tabular}{|llcllc|}
\hline IIller & $\begin{array}{l}\text { Suriyeli } \\
\text { Sayısı }\end{array}$ & il Nüfusuna Oranı $(\%)$ & Iller & $\begin{array}{l}\text { Suriyeli } \\
\text { Sayısı }\end{array}$ & il Nüfusuna Oranı (\%) \\
\hline Kilis & 109,980 & 75,78 & Mersin & 221,870 & 12,06 \\
\hline Hatay & 433,012 & 26,58 & Bursa & 178,154 & 5,83 \\
\hline Gaziantep & 450,611 & 21,78 & Konya & 117,776 & 5,28 \\
\hline Şanlıurfa & 421,367 & 20.32 & İzmir & 147,457 & 3,38 \\
\hline Adana & 251,634 & 11,24 & İstanbul & 517,345 & 3,33 \\
\hline
\end{tabular}

Kaynak: (www.goc.gov.tr/gecici-koruma5638)

Suriyelileri konu alan saha araştırmalarında, en çok örneklem alınan ilk beş il İstanbul, Kilis, Gaziantep, Şanlıurfa ve Ankara'dır. Göç İdaresinin 2021 Haziran ayı geçici koruma altındaki Suriyelilerin yaşadığı illere göre nüfus yoğunluğu verilerine göre ilk beş il ise Kilis, Hatay, Gaziantep, Şanlıurfa ve Adana'dır. Nüfus yoğunluğu bakımından 10. sırada ve toplam Suriyeli nüfus sayısı bakımından 1. sırada yer alan İstanbul alan araştırmasında en çok çalışmanın yapıldığı ili oluşturmaktadır. Bunda hem yaklaşık 517 bin Suriyeliyi barındırması hem de üniversite sayısının fazlalığı etki etmektedir. İlk on içinde yer almayan Ankara ise en çok alan araştırması yapılan 5. il konumundadır. Bunda başkent olmasının ve görece üniversite sayısının fazlalığ etki etmektedir. Yaklaşık 433 bin ile en çok ikinci Suriyeli nüfusunu barındıran Hatay ise 12 saha çalışması ile ancak 7. sırada yer almıştır.

Tablo 7. Yazın Çalışmalarında Örneklem Olarak Yer Alan Yükseköğretim Gören Öğrencilerinin Eğitim Gördükleri Üniversiteler

\begin{tabular}{|llll|}
\hline \multicolumn{1}{|c}{ ÜNIVERSITE } & SAYI & ÜNIVERSITE & SA YI \\
\hline Adıyaman Üniversitesi & $\mathbf{1}$ & Gaziantep Üniversitesi & $\mathbf{1}$ \\
\hline Akdeniz Üniversitesi & $\mathbf{1}$ & Harran Üniversitesi & $\mathbf{1}$ \\
\hline Ankara Üniversitesi & $\mathbf{1}$ & İstanbul Üniversitesi & $\mathbf{1}$ \\
\hline Aydın Üniversitesi & $\mathbf{1}$ & Kahramanmaraş Sütçü İmam Üniversitesi & $\mathbf{1}$ \\
\hline Bayburt Üniversitesi & $\mathbf{1}$ & Karabük Üniversitesi & $\mathbf{1}$ \\
\hline Bursa Üniversitesi & $\mathbf{1}$ & Mersin Üniversitesi & $\mathbf{1}$ \\
\hline Çukurova Üniversitesi & $\mathbf{1}$ & Necmettin Erbakan Üniversitesi & $\mathbf{1}$ \\
\hline Dokuz Eylül Üniversitesi & $\mathbf{1}$ & Osmaniye Korkut Ata Üniversitesi & $\mathbf{2}$ \\
\hline Düzce Üniversitesi & $\mathbf{1}$ & Uşak Üniversitesi & $\mathbf{1}$ \\
\hline Ege Üniversitesi & $\mathbf{1}$ & Van Yüzüncü Yı Üniversitesi & $\mathbf{1}$ \\
\hline Erciyes Üniversitesi & $\mathbf{1}$ & TOPLAM & $\mathbf{2 1}$ \\
\hline
\end{tabular}


Tablo 7 incelendiğinde, saha araştırmasında toplamda 21 üniversitenin kullanıldığı tespit edilmiştir. Ayrıca, en fazla Osmaniye Korkut Ata Üniversitesi'ndeki eğim gören öğrencilerle çalışmaların yapıldığı tespit edilmiştir.

\section{Şekil 6. Suriyelilere Yönelik Tanımlamalar}

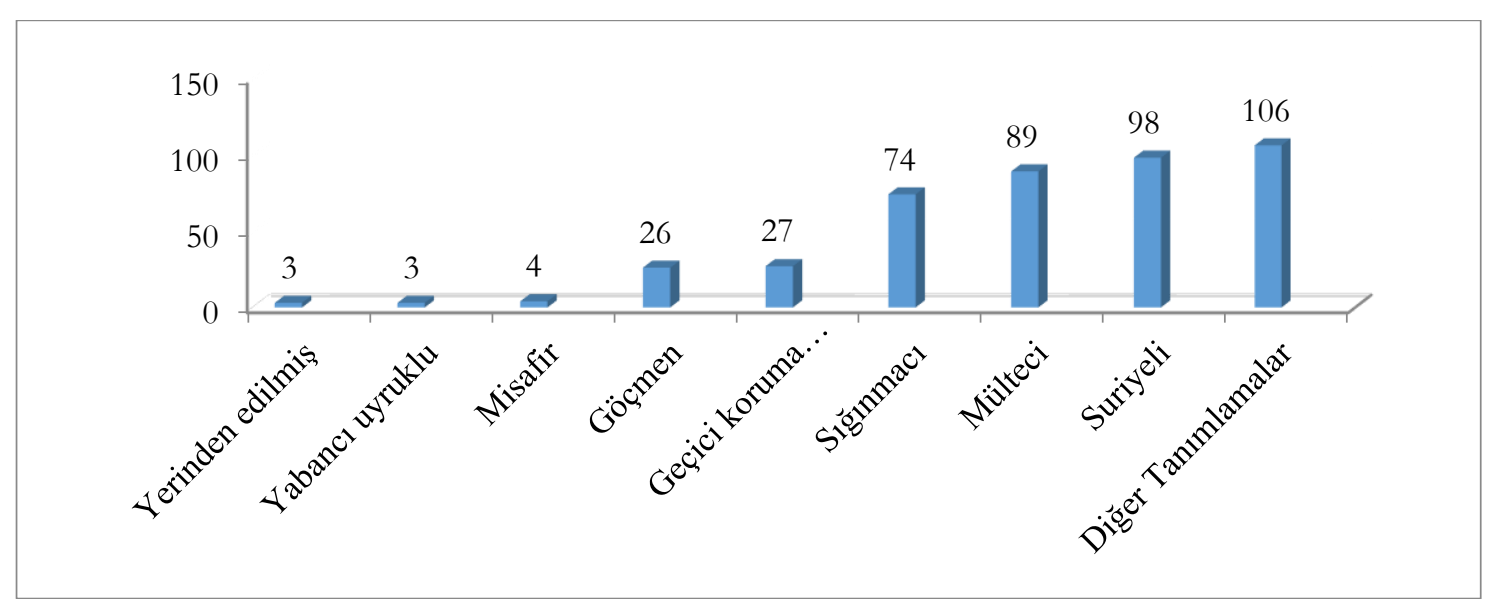

Grafik 6 incelendiğinde, Suriyelileri tanımlamaya yönelik en fazla "Suriyeli" tanımlamasının kullanıldığı, bu tanımlamadan sonra ise en fazla "mülteci" ve "sı̆̆ınmacı" tanımlamalarının kullanıldığ 1 tespit edilmiştir. Hukuki olarak Suriyelilerin geçici koruma altındaki bireyler olarak tanımlanmasına rağmen, yazın çalışmalarında bu tanımlamanın oldukça az kullanıldığı $(\mathrm{f}=27)$ tespit edilmiştir. Bu bağlamda akademik olarak Suriyelilerin hukuki durumunun tam olarak kavranamadığını ifade edilebilir. Bunla birlikte, Suriyelilere yönelik "misafir" tanımlamaları ve Suriyelilerin mağduriyetine vurgu yaparak "yerinden edilmiş" tanımlamalarının da kullanıldı ğı tespit edilmiştir. Son olarak, incelenen bazı yazın çalışmalarında Suriyelilere yönelik mutlak bir tanımlamanın kullanılmadığı tespit edilmiştir. Bu yazın çalışmalarında, Suriyeli göçü kavramının ve yazın çalışmalarında ele alınan konu başlıklarının doğrudan başlık olarak ele alındıkları belirlenmiştir. Bu tür yazın çalışmalarında, mutlak bir Suriyeli tanımlaması yer almadığı için, bu yazın çalışmaları "diğer tanımlamalar ( $\mathrm{f}=106)$ " başlığı altında ele alınmıştır.

\subsection{Suriyeli Göçü Alan Yazınının Nitel Çözümü}

Suriye göçü bağlamında 430 makale ele alınmıştır. Ele alınan yazın çalışmaları, nicel ve nitel olmak üzere iki yönteme dayalı olarak derinlemesine incelenmiştir. $\mathrm{Bu}$ çalışmanın nitel boyutunu, ele alınan yazın çalışmalarının tematik (içerik) çözümlemesi oluşturmaktadır. İçerik çözümleme yöntemi, dokümanlar içerisinde yer alan kavramlarının belli kategorik kodlar altında sınıflandırılarak metin hakkında çıkarımların yapıldığı araştırma analiz yöntemidir (Büyüköztürk vd., 2019: 259). Bu araştırma kapsamında 430 makale, içerik çözümleme yöntemine dayalı olarak tematik kodlar altında değerlendirilerek yazın çalışmalarında Suriyeli göçü analiz edilmiştir.

Tablo 8. Yazın Çalışmalarının Tematik Çözümlemesi

\begin{tabular}{|c|c|c|}
\hline TEMALAR & & \\
\hline \multirow{7}{*}{$\begin{array}{l}\text { ULUSLARARA } \\
\text { SI SURIYYELİ } \\
\text { GÖÇÜ }\end{array}$} & Uluslararası göç & 2 \\
\hline & Suriyeli göçü & 1 \\
\hline & Suriyeli mülteciler & 2 \\
\hline & Suriyeli mülteci sorunu & 2 \\
\hline & Mülteci politikası & 1 \\
\hline & Suriyeli göçüne ev sahipliği & 1 \\
\hline & Yerinden edilmişlik & 1 \\
\hline & TOPLAM & 10 \\
\hline \multirow{6}{*}{ SURIYYELİLER } & Suriyeliler üzerine etnografik çalışma & 1 \\
\hline & Suriye evlilikleri & 1 \\
\hline & Suriyelilerin sosyo-ekonomik durum analizi & 2 \\
\hline & Suriyelilerin sosyo-kültürel durum analizi & 2 \\
\hline & Suriyelilerin yaşadıkları sorunlar & 3 \\
\hline & Suriyelilerin Türkiye'ye yönelik tutumları & 1 \\
\hline
\end{tabular}




\begin{tabular}{|c|c|c|}
\hline & Suriyelilerin aile yapıları & 1 \\
\hline & Suriyelilerin gelecek beklentileri & 2 \\
\hline & TOPLAM & 13 \\
\hline & Suriyeli göçünü yarattığı sorunlar & 2 \\
\hline SURIYYLLI & Suriyelilerin Ürdün'de su problemine neden olmaları & 1 \\
\hline SORUNU & Suriyeli göçün sosyo-ekonomik etki düzeyi & 3 \\
\hline & Suriyeli göçün kültürel etki düzeyi & 1 \\
\hline & TOPLAM & 7 \\
\hline & Savaş ve çocuk & 1 \\
\hline & Göç ve çocuklar & 1 \\
\hline ÇOCUK & Suriyeli çocukların oyun ilişkileri & 2 \\
\hline & Ergenlerin geleceğe dair umutları & 1 \\
\hline & Suriyeli çocuk evliliği & 1 \\
\hline & TOPLAM & 6 \\
\hline & Suriyeli çocukların ailevi ilişkileri & 1 \\
\hline AİLE & Eğitimde ebeveyn görüşleri & 1 \\
\hline & Suriyeli annelerin çocuk eğitiminde yeterlilik düzeyleri & 1 \\
\hline & TOPLAM & 3 \\
\hline & Yabancı dil öğreniminde karşılaşılan sorunlar & 3 \\
\hline & Yabancı dil olarak Türkçe öğretimi & 2 \\
\hline & Türkçe dersinde materyal kullanımı & 1 \\
\hline & Türkçe ders kitaplarının incelenmesi & 2 \\
\hline & Cocuklarda kelime envanteri & 1 \\
\hline & Okula uyum & 2 \\
\hline & Okula uyumda spor aktiviteleri & 1 \\
\hline & Okul kültürü & 2 \\
\hline & Okulda disiplin sorunları & 1 \\
\hline & Eğitim politikası & 3 \\
\hline & Eğitim hizmetlerinin öğretmenler tarafindan değerlendirilmesi & 2 \\
\hline & Eğitimde öğretmenlerin görüşleri & 3 \\
\hline & Öğretmenlerin tükenmişlik düzeyi & 1 \\
\hline & Göçmen/sığınmacı eğitimi & 3 \\
\hline & Suriyeli öğrencilerle karşılaşılan sorunlar & 2 \\
\hline ЕС̆ітіM & İstenilmeyen öğrenci davranışları & 1 \\
\hline EGI IIVI & Öğrencilerin dil ve iletişim sorunları & 4 \\
\hline & Fen bilimleri dersinde karşılașılan sorunlar & 1 \\
\hline & Uyum sürecinde eğitimin önemi & 2 \\
\hline & Öğretmenlerin Suriyeli öğrencilere yönelik görüşleri & 2 \\
\hline & Suriyeli öğrencilerin eğitim durumu ve okullaşma durumları & 5 \\
\hline & Suriyeli öğrencilerin eğitimde karşılaştıkları sorunlar & 10 \\
\hline & Suriyeli çocukların eğitimde sosyal beceri düzeyleri & 1 \\
\hline & Suriyeli öğrencilerin Türkçe dersine yönelik değerlendirmeleri & 1 \\
\hline & Suriyeli öğrencilerin Türkçe öğretmenlerine yönelik algı düzeyleri & 2 \\
\hline & Eğitimde entegrasyon & 4 \\
\hline & Eğitim sorunu & 3 \\
\hline & Yabancı öğrencilerin eğitiminde okullar arası işbirliği & 1 \\
\hline & Geçici eğitim merkezlerinde (GEM) karşılaşılan sorunlar & 1 \\
\hline & Suriyeli Üniversiteli öğrencilerin sosyo-ekonomik durum analizi & 4 \\
\hline & Yükseköğrenim gören Suriyelilerin eğitimde karşılaştıkları sorunlar & 5 \\
\hline & Yükseköğrenim gören Suriyeli öğrencilerde yılmazlık & 1 \\
\hline & TOPLAM & 77 \\
\hline & Çocuklarda tanrı algisı & 1 \\
\hline & Din ve kadın & 1 \\
\hline & Suriyelilerin dini yaşamaları & 1 \\
\hline DIN & Başa çıkma mekanizmasında din & 1 \\
\hline & Dini motivasyon kaynağı Kuran-1 Kerim & 1 \\
\hline & İmam hatip liselerinde eğitim gören Suriyeli öğrencilerin eğitimde karşılaştıkları sorunlar & 1 \\
\hline
\end{tabular}




\begin{tabular}{|c|c|c|}
\hline & Suriyeli öğrencilerin din derslerinde karşılaştıkları sorunlar & 2 \\
\hline & Sekülerleşme ve göç & 1 \\
\hline & Göç teolojisi & 1 \\
\hline & TOPLAM & 10 \\
\hline \multirow{19}{*}{ MEDYA } & Medyada Suriyelilere yönelik algı & 6 \\
\hline & Medyada Suriyelilere yönelik nefret söylemleri & 1 \\
\hline & Medyada ötekileşen Suriyeliler & 2 \\
\hline & Medyada Suriyeliler ile yerel halk arasındaki ilişki düzeyi & 1 \\
\hline & Medyada Suriyeli kadınlar & 1 \\
\hline & Medyada çocuklar & 2 \\
\hline & Youtube'da Suriyelilere yönelik nefret söylemleri & 1 \\
\hline & Okur yorumlarında Suriyeliler & 3 \\
\hline & Web sitelerinde Suriyeliler & 1 \\
\hline & Yerel basında Suriyeliler & 1 \\
\hline & Haberlerde yabancı dil olarak Türkçe öğretimi & 1 \\
\hline & Sosyal medyada Suriyelilere yalan haberler & 1 \\
\hline & Sosyal medyada Suriyelilere yönelik alg1 & 1 \\
\hline & Sosyal medyada Suriyeli görseller & 1 \\
\hline & Haberlerde Suriyeliler & 1 \\
\hline & Haberlerde ayrımcı metaforlar & 1 \\
\hline & Haberlerde ötekileşen Suriyeliler & 1 \\
\hline & Haberlerde çocuk işçiliği & 1 \\
\hline & Siber mekânda faşizm söylemleri & 1 \\
\hline & TOPLAM & 28 \\
\hline \multirow{7}{*}{ SANAT } & Göçmen filmlerinde göçmen kaçakçılığı & 1 \\
\hline & Filmlerde Suriyelilerin mağduriyetleri & 1 \\
\hline & Sinemada Suriyeliler & 1 \\
\hline & Suriyeli müzisyenler & 1 \\
\hline & Çocuk edebiyatında mülteciler & 1 \\
\hline & Çocuk edebiyatında mülteci kahramanlar & 1 \\
\hline & Romanlarda Suriyeliler & 2 \\
\hline & TOPLAM & 8 \\
\hline \multirow{16}{*}{ KADIN } & Savaş ve Kadın & 1 \\
\hline & Kadın ve güvenlik & 1 \\
\hline & Yalnız kadınlar & 1 \\
\hline & Suriyeli göçmen kadınlar & 1 \\
\hline & Kadınların mevcut durumları ve sorunları & 3 \\
\hline & Küreselleşme ve kadın & 1 \\
\hline & Kadınlarda başa çıkma mekanizması evlilikler & 1 \\
\hline & Suriyeli kadınlar kurban ya da sosyal girişimci & 1 \\
\hline & Suriyeli kadınların entegrasyon düzeyleri & 1 \\
\hline & Kadınların sosyo-kültürel değişimleri & 1 \\
\hline & Kadınların sosyal dışlanma algısı & 1 \\
\hline & Suriyeli kadınların entegrasyon sürecinde sosyal ağların önemi & 1 \\
\hline & Suriyeli kadınların yardım gruplaşmaları & 1 \\
\hline & Kadınların işgücü piyasasına katılımı & 1 \\
\hline & İş piyasasında kadınların yaşadıkları ayrımcılık & 1 \\
\hline & Toplumsal cinsiyet bağlamında göç mevzuatının değerlendirilmesi & 1 \\
\hline & TOPLAM & 18 \\
\hline \multirow{8}{*}{ KENTLEŞME } & Kent tercihleri & 2 \\
\hline & Kent kuramları bağlamında Suriyeliler & 1 \\
\hline & Kentsel uyum & 2 \\
\hline & Suriyelilerin kentteki etki düzeyleri & 1 \\
\hline & Kentte güvenlik sorunu & 1 \\
\hline & Mekânsal yapı üzerindeki etki düzeyi & 1 \\
\hline & Geçici barınma merkezleri & 1 \\
\hline & TOPLAM & 9 \\
\hline
\end{tabular}




\begin{tabular}{|c|c|c|}
\hline \multirow{27}{*}{ KÜLTÜR } & Mültecilerin Algıları & 1 \\
\hline & Uyum & 6 \\
\hline & Sosyal uyum & 4 \\
\hline & Sosyal uyum önündeki engeller & 1 \\
\hline & Toplumsal kabul & 3 \\
\hline & Entegrasyon & 4 \\
\hline & Kültürel uyum & 4 \\
\hline & Kültürel uyumda din & 1 \\
\hline & Kültürel uyumda okul & 1 \\
\hline & Kültürel uyumda okuldaki rehberlik danışmanlarının rol ve sorumlulukları & 1 \\
\hline & Farklı değerlere sayg1 & 1 \\
\hline & Sosyal sinif & 1 \\
\hline & Sosyal sermaye & 1 \\
\hline & Önyarg1 & 1 \\
\hline & Yabanc1 & 1 \\
\hline & Sosyal dişlanma & 2 \\
\hline & Suriyelilere yönelik önyargılların Türkmen öğrencilere yansıması & 1 \\
\hline & Çokkültürlülük & 3 \\
\hline & Suriyelilere yönelik algı, tutumlar ve bakış açısı & 11 \\
\hline & Yerel halk ve Suriyeliler & 1 \\
\hline & Üniversite öğrencilerinin Suriyeli mülteci kavramına yönelik tutumları & 1 \\
\hline & Üniversite öğrencilerinin Suriyelilere yönelik tutumları & 4 \\
\hline & Öğrencilerin(orta okul, lise) Suriyelilere yönelik tutumları & 2 \\
\hline & Suriyeli öğrencilere yönelik tutum ölçeği & 1 \\
\hline & Dil eğitimi ve Türkçe ihtiyacı & 3 \\
\hline & Suriyelilerin dil öğrenme süreçleri & 1 \\
\hline & İletişim sorunu & 2 \\
\hline & TOPLAM & 64 \\
\hline \multirow{29}{*}{ EKONOMI } & Suriyeli göçün iktisadi değerlendirmesi & 3 \\
\hline & Ekonometrik analiz & 1 \\
\hline & Suriyeli göçün ekonomi üzerindeki etkisi & 7 \\
\hline & Kentlerin emek piyasasındaki değişimi & 1 \\
\hline & Suriyelilerin istihdamı & 3 \\
\hline & Suriyelilerin istihdam problemleri & 2 \\
\hline & Suriyelilerin çalışma koşulları & 2 \\
\hline & İşgücü piyasasında entegrasyon & 2 \\
\hline & Mesleki eğitim ve istihdam & 1 \\
\hline & Çalışma hakkı & 2 \\
\hline & Çalışma İzni & 1 \\
\hline & Maliyet & 1 \\
\hline & Ekonomik külfet & 1 \\
\hline & İşsizlik & 2 \\
\hline & Kayıt dışı istihdam & 4 \\
\hline & Suriyelilerin vergi adaleti üzerindeki etki düzeyleri & 1 \\
\hline & Girişimcilik & 4 \\
\hline & Diaspora girişimcilik & 1 \\
\hline & Mülteci girişimciliği & 1 \\
\hline & Mülteci restoranlar & 1 \\
\hline & Girişimcilik faaliyetlerinde CEESCALE ölçeği & 1 \\
\hline & Yerel esnafin Suriyelilere yönelik algı düzeyleri & 2 \\
\hline & Çocuk işçiliği & 3 \\
\hline & Sokakta çalışan çocuklar & 1 \\
\hline & Tekstil sektöründe Suriyeli çocuklar & 1 \\
\hline & Suriyelilerin vergi algıs1 & 1 \\
\hline & Kapitalist üretim ilişkisinde Suriyeliler & 1 \\
\hline & Ekonomi hukuku bağlamında Suriyeliler & 1 \\
\hline & TOPLAM & 52 \\
\hline
\end{tabular}




\begin{tabular}{|c|c|c|}
\hline \multirow{7}{*}{$\begin{array}{l}\text { SOSYAL } \\
\text { HIZMETLER } \\
\text { VE STK'LAR }\end{array}$} & Suriyelilere yönelik sivil toplum kuruluşlarının faaliyetleri & 1 \\
\hline & Uluslararası örgütler ve STK'ların insani yardımları & 1 \\
\hline & Suriyelilere yapılan sosyal hizmetler & 2 \\
\hline & AFAD & 1 \\
\hline & Sosyal politika aracı olarak yetimhaneler & 1 \\
\hline & İnsani yardımlar & 1 \\
\hline & Gençlik merkezlerindeki hizmet kalitesi & 1 \\
\hline & TOPLAM & 8 \\
\hline \multirow{6}{*}{ YÖNETIM } & Göç yönetimi & 2 \\
\hline & Göç yönetişimi & 2 \\
\hline & Göç politikası & 3 \\
\hline & Kamu politikaları ve uyum & 1 \\
\hline & Kamu kurumları ile uyum & 1 \\
\hline & Suriyeli göçün kamu politikaları üzerindeki etki düzeyi & 1 \\
\hline & TOPLAM & 10 \\
\hline \multirow{6}{*}{$\begin{array}{l}\text { SIYYASA VE } \\
\text { YEREL } \\
\text { YÖNETIMLER }\end{array}$} & Siyasi partilerin Suriyelilere yönelik politikaları & 1 \\
\hline & Politik gençlik örgütlerinin Suriyelilere yönelik söylemleri & 2 \\
\hline & Siyasallaşma & 1 \\
\hline & Suriyelilerin siyasi durumları & 1 \\
\hline & Yerel yönetimler ve yabancılar & 1 \\
\hline & Belediyelerin sorumlulukları & 1 \\
\hline & TOPLAM & 7 \\
\hline \multirow{5}{*}{ GÜVENLİK } & Güvenlik & 5 \\
\hline & Sınır güvenliği & 1 \\
\hline & İnsan güvenliği & 1 \\
\hline & Düzensiz göçle mücadele & 1 \\
\hline & Yasadışı göç & 1 \\
\hline & TOPLAM & 9 \\
\hline \multirow{7}{*}{ DİPLOMASİ } & Suriyeli göçünün TR-AB ilişkilerine yansıması & 1 \\
\hline & TR-AB üyelik sürecinde göç yönetimi & 2 \\
\hline & TR-AB geri kabul anlaşmasında Suriyeliler & 1 \\
\hline & TR-AB Suriyelilere yönelik insani tutumları & 1 \\
\hline & AB bağlamında uluslararası göç & 2 \\
\hline & Komşu ülkelerin Suriyelilere yönelik politikaları & 1 \\
\hline & Türkiye ve Almanya'nın Suriyelilere yönelik sağladıkları hakların değerlendirmesi & 1 \\
\hline & TOPLAM & 9 \\
\hline \multirow{17}{*}{ HUKUK } & Mülteci hukuku & 3 \\
\hline & İnsan hakları & 1 \\
\hline & Sosyal güvenlik hakkı & 1 \\
\hline & Uluslararası hukukta Suriyeliler & 1 \\
\hline & Suriyeli kaynaklı göç mevzuatı & 1 \\
\hline & Yabancılar ve uluslararası koruma & 4 \\
\hline & Uluslararası koruma & 4 \\
\hline & Geçici Koruma Yönetmeliği & 3 \\
\hline & Geçici koruma rejimi & 2 \\
\hline & Geçici koruma statüsü & 2 \\
\hline & Coğrafi kısıtlama & 2 \\
\hline & Suriyelilerin hukuki statüsü & 7 \\
\hline & Suriyelilerin iç hukuktaki durumları & 1 \\
\hline & Suriyelilerin sosyal, siyasi ev vatandaşlık hukuku bakımından değerlendirmesi & 1 \\
\hline & Yasal entegrasyon & 2 \\
\hline & Suriyeli çocuk evliliğinin hukuki geçerliliği & 1 \\
\hline & TOPLAM & 36 \\
\hline \multirow{4}{*}{ VATANDAŞLIK } & Vatandaşlık hakkı & 1 \\
\hline & Misafirlikten vatandaşlığa & 1 \\
\hline & Suriyelilerin vatandaşlığı ilişkin görüşleri & 1 \\
\hline & TOPLAM & 3 \\
\hline
\end{tabular}




\begin{tabular}{|c|c|c|}
\hline & Suriyelilerin sağlık durumları & 1 \\
\hline & Savaş yaralanmaları ve ateşli yaralanmalar & 4 \\
\hline & Yanık vakaları & 1 \\
\hline & Göz yaralanmaları & 1 \\
\hline & Depresyon ve ruhsal hastalıklar & 2 \\
\hline & Diş çürüklüğü & 1 \\
\hline & Hepatit B & 1 \\
\hline & Hidrosefali & 1 \\
\hline & Pediatrik pyodermagangrenozum & 1 \\
\hline & Kabızlık & 1 \\
\hline & Tüberküloz & 2 \\
\hline & Retrospektif & 1 \\
\hline & Perinatal & 1 \\
\hline & Kadın hastalıkları & 3 \\
\hline & Jilet yutan kadın & 1 \\
\hline & Obezite & 1 \\
\hline & Bulaşıcı hastalıklar & 1 \\
\hline & Acil toraks yaralanmaları & 1 \\
\hline & Mülteci cinnetleri & 1 \\
\hline SAĞLIK & Fiziksel sağlık & 1 \\
\hline & Hayvansal ürün tüketimi & 1 \\
\hline & Covid-19'un Suriyelilere etkisi & 1 \\
\hline & Psikososyal & 1 \\
\hline & Ergenlerin psikososyal durumları & 1 \\
\hline & LGBTIQQ+ Mültecilerin sağlık ihtiyaçları & 1 \\
\hline & Sağlık politikaları & 4 \\
\hline & Sihhat projesi & 1 \\
\hline & Toplum sağlı̆̆ı & 1 \\
\hline & Sağlık hakk1 & 2 \\
\hline & Sağlık yardımları & 1 \\
\hline & Sağlık hizmetlerine erişim & 2 \\
\hline & Sağlık okuryazarlığı & 1 \\
\hline & Savaşın acil servise etkisi & 2 \\
\hline & Suriyeli hastalarla Türk hastalarının karşılaştırılması & 2 \\
\hline & Suriyeli doktorların sağlık sistemine adaptasyonu & 1 \\
\hline & Sağlık çalışanlarının yaşadıkları sorunlar & 1 \\
\hline & Sağlık çalışanlar ile iletişim & 2 \\
\hline & Sağlık personellerinin iş yükü & 1 \\
\hline & Suriyelilerin sağlık hizmetleri üzerindeki etki düzeyleri & 1 \\
\hline & TOPLAM & 54 \\
\hline & Göç teorileri & 2 \\
\hline & Göç kuramları & 2 \\
\hline KURAMSAL & Göç çalışmaları & 1 \\
\hline & Göç kuramları ve Suriyeliler & 1 \\
\hline & Literatür taraması & 3 \\
\hline & TOPLAM & 9 \\
\hline TOPLAM & & 450 \\
\hline
\end{tabular}

Yukarıdaki tabloda, uluslararası göç bağlamında Suriyelileri konu alan yazın çalışmalarının içerik analiz yöntemine dayalı olarak çözümlenen tematik kodlamalar yer almaktadır. İncelenen yazın çalışmaları sonucu, toplamda 22 alt temada 450 koda ulaşılmıştır. İncelenen bazı yazın çalışmalarında, bir başlıktan birden fazla koda ulaşılmıştır. İncelenen yazın çalışmalarında, en fazla tematik kodlamalarının eğitim teması (f=77) başlığı altında ele alındığı tespit edilmiştir. Eğitim temasında sıklıkla tekrarlanan kodun ise Suriyeli öğrencilerin eğitimde karşılaştıkları sorunlar ( $\mathrm{f}=10)$ olduğu tespit edilmiştir. Eğitim temasından sonra tematik kodların en fazla yer aldığı tema kültür ( $\mathrm{f}=64$ ) temasıdır. Kültür temasında sıklıkla tekrarlanan kodun ise Suriyelilere yönelik algı ve tutum ( $\mathrm{f}=11$ ) olduğu tespit edilmiştir. Kültür temasından sonra tematik kodların en fazla yer aldığı tema sağlık ( $\mathrm{f}=54)$ alanıdır. Sağlık alanında sıklıkla tekrarlanan kodlar ise savaş yaralanmaları ( $\mathrm{f}=4)$ ve 
sağlık politikalarının ( $\mathrm{f}=4$ ) olduğu tespit edilmiştir. Sağlık alanından sonra en fazla ele alınan temalar ise ekonomi $(\mathrm{f}=45)$ ve hukuk $(\mathrm{f}=36)$ temalarıdır. Ekonomi alanında sıklıkla tekrarlanan kodun Suriyeli göçün ekonomik etkileri ( $\mathrm{f}=8)$ olduğu, hukuk alanında sıklıkla tekrarlanan kodun ise Suriyelilerin hukuki statüsü $(\mathrm{f}=7)$ olduğu tespit edilmiştir. Ayrıca incelenen yazın çalışmalarında, hukuki bağlamda ele alınan yazın çalışmalarında farklı bir tema olarak "Suriyeli çocuk evliliklerinin" ele alındığı tespit edilmiştir. Ulusu Karataş (2020), tarafından kaleme alınan yazın çalışmasında, Suriyeli çocuk evliliklerinin yasal düzenlemelerdeki geçerlilik düzeyi, ulusal ve Suriyeli hukuki düzenlemeler bağlamında karşılaştırmalı olarak incelenmiştir.

Uluslararası Suriyeli göç teması başlığı altında en fazla kodun "Suriyeli mülteci sorunu" bağlamında ele alındığı tespit edilmiştir. Suriyeliler teması başlı̆̆ı altında en fazla ele alınan kodun "Suriyelilerin yaşadıkları sorunlar" bağlamında ele alındığı tespit edilmiştir. Suriyeli teması başlığı altında en fazla kodun "Suriyeli göçün sosyo-ekonomik etki düzeyi" bağlamında ele alındığı tespit edilmiştir. Din teması başlığı altında en fazla kodun "Suriyeli öğrencilerin din derslerinde karşılaştıkları sorunlar" bağlamında ele alındıkları tespit edilmiştir. Medya teması başlığı altında en fazla kodun "okur yorumlarında Suriyeliler" bağlamında ele alındığı tespit edilmiştir. Sanat teması başlığı altında en fazla kodun "romanlarda Suriyeliler" bağlamında ele alındığı tespit edilmiştir. Kadın teması başlığı altında en fazla kodun "kadınların mevcut durumu ve sorunları" bağlamında ele alındıkları tespit edilmiştir. Ayrıca toplumsal cinsiyet bağlamında ele alınan yazın çalışmalarında dikkat çeken kodlardan biri de "LGBTİ+ bireylerin sağlık ihtiyaçları" ve "toplumsal cinsiyet bağlamında hukuki mevzuatın değerlendirmesi” başlıklarıdır. Beycan Ekitli vd., (2021) Suriyeli LGBTiQ+ bireyleri sağlık hizmetlerinden yararlanma düzeyleri bakımından, Cavlak ve Doğan (2018) ise ulusal hukuki düzenlemeler çerçevesinde hukuki korunmaları çerçevesinde ele almıştır. Kentleşme teması başlığı altında en fazla kodun "kentsel uyum" bağlamında ele alındığı tespit edilmiştir. Sosyal Hizmet ve STK'lar teması başlığı altında en fazla kodun "Suriyelilere yönelik yapılan sosyal hizmetler" başlığı altında ele alındığ 1 tespit edilmiştir. Yönetim teması başlığı altında en fazla kodun "göç politikası" bağlamında ele alındığı tespit edilmiştir. Siyasa ve Yerel Yönetimler teması başlığı altında en fazla kodun "politik gençlik örgütlerinin Suriyelilere yönelik söylemler” başlı̆g 1 altında ele alındığı tespit edilmiştir. Bayram (2020) ve Bayram (2021) tarafından kaleme alınan çalışmada, siyasa gençlik örgütlenmelerinin Suriyelilere yönelik söylemleri medya aracılığı ile incelenmiştir. Güvenlik teması başlığı altında en fazla kodun "güvenlik" bağlamında ele alındığ1 tespit edilmiştir. Diplomasi teması başlığı altında en fazla kodun "TR-AB üyelik sürecinde göç yönetimi" başlığı altında ele alındığı tespit edilmiştir. Kuramsal tema başlığı altında ise en fazla kodun "literatür tarama" bağlamında ele alındığı tespit edilmiştir.

\section{SONUÇ}

İncelenen yazın çalışmaları sonucunda, 2011 yılında patlak veren Suriyeli göçüyle birlikte, uluslararası göç bağlamında Suriyelilere yönelik yazın çalışmalarında artışların yaşandığ uluslararası göç bağlamında Suriyelilere yönelik yazın çalışmalarının 2015 yılından sonra artışların yaşandığı tespit edilmiştir. Suriyeli göçü bağlamında, 2012 ve 2014 yılları arasında ele alınan çalışmaların daha çok sağlık ve hukuk bağlamında ele alındığı tespit edilmiştir. Ancak, ilerleyen süreçlerde Suriyelilerin kalıcı olmasıyla birlikte 2015 yılında Suriye göçüne yönelik çalışmalarda artışların yaşandığı ve göçün sosyal, kültürel, ekonomik, yönetimsel ve siyasal boyut olmak üzere farklı alanlar üzerinden de ele alındığı tespit edilmiştir. Bununla birlikte, incelenen yazın çalışmalarında en fazla yazın çalışmalarının 2018 yılında ele alındığı tespit edilmiştir. Ayrıca, genel anlamda uluslararası göç alanında Suriye göçünün önemli bir yer kapladığı ve Suriyeli mültecilerin kalıcı olmasıyla birlikte ilerleyen zamanlarda da uluslararası göç alanında Suriye göçünün önem ve niceliğinin artacağ 1 öngörülmektedir. İncelenen yazın çalışmalarında niceliksel olarak üzerinde durulan konuların çoğunluğunun, sosyal bağlamda ele alındığı tespit edilmiştir. Sosyal boyuttan sonra ele alınan çalışmaların niceliksel olarak sıralanması ise şu şekildedir; kültürel boyut, ekonomik boyut, sağlık boyut, hukuki boyut, yönetimsel boyut, kavramsal boyut, küreselleşme ve siyasi boyuttur.

Suriye göçü bağlamında ele alınan yazın çalışmalarının çoğunluğunun sosyal bağlamda ele alındığı ve bu çalışmalarının ise çoğunlukla Suriyeli çocukların eğitimi, Suriyeli mültecilerin sosyal medyadaki konumu ve Suriyeli mültecilerin sorun ve etkileri bağlamında ele alındığı tespit edilmiştir. Çocukların eğitimini konu alan çalışmalar ağırlıklı olarak temel eğitim sürecindeki anaokul, ilkokul ve ortaokul düzeyindeki öğrenciler üzerine alındığı, yükseköğrenim düzeyinde ele alınan çalışmaların ise oldukça az olduğu tespit edilmiştir. Ayrıca, yükseköğrenim gören öğrencileri konu alan çalışmaların ise daha çok kültürel bağlamda ele alındığı tespit edilmiştir. Eğitim alanından sonra üzerinde en fazla çalışmanın ele alındığı konu ise medyadır. Bu çalışmalarda, daha çok Suriyelilere yönelik olumsuz söylemlerin analiz edildiği ve bu söylemlerin genellikle gazete başlıklarının üzerinden incelendiği tespit edilmiştir. Sosyal bağlamda üzerinde önemle durulan diğer bir başlık ise mültecilerin göç sırasında ve göç sonrasında karşılaştıkları sorunlar ve Suriyeli göçünün 
Türkiye'ye etkisidir. Sosyal bağlamda kadınları konu alan yazın çalışmaları incelendiğinde, özel olarak kadınları konu edinen yazın çalışmalarının sınırlı sayıda olduğu tespit edilmiştir. Oysa ki kadınların hem biyolojik hem de psikolojik olarak göçün en büyük mağdurları olduğu ve bu nedenle kadınlar üzerine daha fazla çalışmaların ele alınması gerektiği önerilmektedir.

Kültürel bağlamda ele alınan yazın çalışmaları incelendiğinde, ele alınan çalışmaların çoğunluğunun entegrasyon ve yerel halk ile Suriyeli mülteciler arasındaki algı düzeyi bağlamında ele alındığı tespit edilmiştir. Yerel halk ve Suriyeliler arasındaki algı düzeyini ele alan çalışmaların örnekleminde genellikle, yükseköğrenim gören öğrencilerin kullanıldığı tespit edilmiştir. Kültürel bağlamda ele alınan çalışmalarda ise ağırlıklı olarak 2018-2019 dönemleri arasında ele alındığı tespit edilmiştir. Ayrıca, kültürel bağlamda incelenen diğer yazın çalışmalarından farklı bir konu ise mutfak kültürüdür. Suriye göçünün mutfak kültürü üzerindeki etkisini konu alan ilk çalışmanın 2018 yılında kaleme alındığı tespit edilmiştir.

Ekonomi bağlamında ele alınan yazın çalışmaların üzerinde durduğu başlıca konuların Suriye göçünün Türkiye ekonomisine etkileri, Suriyelilerin istihdamı ve Suriyelilerin çalışma sorunları bağlamında ele alındıkları tespit edilmiştir. İncelenen yazın çalışmalarında, ekonomi alanında ilk kez 2012 yılında çalışmanın kaleme alındığ 1 ve bu çalışmanın da göç kuramları ve ekonomi ilişkisi bağlamında ele alındığı tespit edilmiştir. Ancak, ekonomi alanında ele alınan çalışmaların genellikle 2016-2019 yılları arasında artış gösterdiği ve son yıllarda ekonomi alanında "vergi" konusunun gündeme alındığı tespit edilmiştir.

Hukuki bağlamda ele alınan yazın çalışmaları incelediğinde ise yazın çalışmalarının genellikle mülteciler hukuku, yabancılar ve uluslararası koruma kanunu, geçici koruma kanunu ve vatandaşlık hakkı bağlamında ele alındığı tespit edilmiştir. Hukuk alanında ele alınan ilk yazın çalışmalarının 2012-2013 yılları arasında ele alındığı ve bu alanların daha çok mülteciler hukuku ve yabancılar ve uluslararası koruma kanunu bağlamında ele alındığı tespit edilmiştir. Ayrıca, hukuk alanındaki çalışmalarda ağırlıklı olarak 2016-2018 yılları arasında ele alındığı tespit edilmiştir. Hukuki bağlamda, incelenen yazın çalışmalarından farklı bir boyutta ele alınan çalışmalardan bir diğeri ise uluslararası mülteciler ve koruma kanunun toplumsal cinsiyet bağlamında ele alınması ve Suriyeli çocuk evliliklerinin Türk mevzuatınca ele alınmasıdır. Toplumsal cinsiyet alanında ilk çalışmanın 2016 yılında ve yakın tarihte ise 2018 yılında ele alındığı tespit edilmiştir. Sosyal alanda olduğu gibi hukuki alanda da kadınların ikinci planda kaldığı bu konuda yeterli çalışmaların olmadığı görülmektedir.

Sağlık alanında ele alınan yazın çalışmaları incelendiğinde, çalışmaların daha çok Suriyelilerin sağlık sorunları, Suriyelilerin sağlık hizmetlerine erişimi ve Suriyelilere sağlanan sağlık politikaları bağlamında ele alındığı tespit edilmiştir. Suriyelilerin sağlık durumlarını ele alan çalışmaların başlıklarının genellikle savaş yaralanmaları ve kadın hastalıkları olduğu tespit edilmiştir. İncelenen yazın çalışmalarında ilk çalışmanın 2013 yılında ele alındığı ancak 2016-2019 yılında artışların yaşandığı tespit edilmiştir.

Küreselleşme bağlamında ele alınan çalışmalar, incelendiğinde ise çalışmaların çoğunluklu olarak Avrupa birliği ve AB-Türkiye arasındaki göç yönetimi bağlamında ele alındığı ve Suriye göçüyle birlikte AB-TR göç yönetim alanındaki çalışmaların 2015-2020 yılları arasında artış yaşandığı tespit edilmiştir.

Siyasal bağlamda ele alınan çalışmaların temel odak noktası yerel yönetimler ve sivil toplum kuruluşlarının olduğu tespit edilmiştir. Bu alandaki yazın çalışmalarının daha çok 2016-2020 yılları arasında ele alındığı tespit edilmiştir. Yönetimsel bağlamda ele alınan yazın çalışmaları incelendiğinde de yazın çalışmalarının daha çok göç yönetimi ve güvenlik politikaları bağlamında ele alındığı ve özellikle 2015-2017 yılları arasında bu çalışmalarda artışların yaşandığı tespit edilmiştir. Yönetimsel bağlamda, incelenen diğer yazın çalışmalarından farklı bir konuya değinen çalışmalardan biri de Suriyelilerin kamusal kurumlarla olan uyum düzeyidir. Kuramsal bağlamdaki yazın çalışmaları incelendiğinde ise ele alınan çalışmaların genellikle göç kuramları ve göç çözümleme bağlamında ele alındığı tespit edilmiştir.

Uluslararası göç bağlamında Suriyeli göçü incelendiğinde, genel olarak çalışmaların daha çok sosyal, ekonomik ve kültürel bağlamda ele alındığ 1 ancak kuramsal bağlamda ele alınan çalışmaların sınırlı olduğu tespit edilmiştir. Uluslararası göç dinamiklerinin daha iyi anlaşılması ve buna bağlı olarak Suriyeli göç mekanizmasının daha iyi anlaşılması için uluslararası göç kuramlarının Suriyeli göçü bağlamında ele alınması önerilmektedir. İncelenen yazın çalışmalarında, eğitim bağlamında ele alınan yazın çalışmalarının eğitimde yaşanan sorunlar bağlamında, genellikle ilkokul ve ortaokuldaki öğrenciler bağlamında ele alındıkları tespit edilmiştir. Lise ve yükseköğrenim gören öğrenciler bağlamında yazın çalışmaların yetersiz kaldığı tespit edilmiştir. Bu nedenle, eğitim sorunsalı bağlamında ele alınan yazın çalışmalarının lise ve yükseköğrenim gören öğrenciler bağlamında ele alınması önerilmektedir. İncelenen yazın çalışmalarında, kadınlar başlığı altındaki yazın çalışmalarının yetersiz kaldığı görülmektedir. Bu nedenle, göçün dezavantajlı grubunda yer alan kadınları konu alan çalışmalarının niceliksel olarak arttırarak toplumsal cinsiyet farkındalığına katkıda bulunması önerilmektedir. Ayrıca, incelenen yazın çalışmalarında, kentsel bağlamda Suriyeli göçüne yönelik yazın çalışmalarının daha çok ekonomik ve sosyal etki düzeyi bağlamında ele alındığı tespit edilmiştir. Ancak, 
Suriyeli göçünün kentteki fiziki etki düzeyi (çevre sorunları, çarpık kentleşme) bağlamında yazın çalışmalarının oldukça sınırlı olduğu tespit edilmiştir. Bu nedenle, Suriyeli göçünün kentleşme ve çevresel sorunlar bağlamında ele alınması önerilmektedir. 


\section{KAYNAKÇA}

Akbaba, M., ve Özel, G. (2020) “Kilis İli Yöresel Yemeklerinde Suriye Göçünün Gölgesi”, Journal of Tourism and Gastronomy Studies, 8(2), s. 971-982. doi: 10.21325/jotags.2020.590.

Aydın, A. (2018) “Suriyeli Mültecilerin Etkileri Kapsamında Ürdün'de Su Sorunu”, Asia Minor Studies, 6(11), s. 13-26. doi: $10.17067 /$ asm.329947.

Bayram, P. (2020) "Sosyal Medyada Suriyeli Mülteci Krizine İlişkin Konum Alışlar: Türkiye’deki Politik Gençlik Üzerinden Bir Analiz”, Balıkesir Üniversitesi Sosyal Bilimler Enstitüsü Dergisi, 23(44), s. 1213-1251. doi: 10.31795/baunsobed.699018.

Bayram, P. (2021) “Twitter'da Suriyeli Mültecilerin Temsili: Türkiye’deki Politik Gençlik Üzerinden Bir Analiz”, Alanya Akademik Bakış Dergisi, 5(1), s. 301-323. doi: 10.29023/alanyaakademik.708509.

Beycan Ekitli, G., Öztürk Turgut, E., ve Dönmez, A. (2021) "LGBTİQ+ Mültecilerde Sağlık Gereksinimleri”, DEUHFED, 14(1), s. 77-83. doi: 10.46483/deuhfed.765100.

Büyüköztürk, Ş., Kılıç Çakmak, E., Akgün, Ö. E., Karadeniz, Ş., ve Demirel, F. (2019) Eğitimde Bilimsel Araştırma Yöntemleri, Pegem, Akademi Ankara.

Cavlak, H., ve Doğan, M. (2018) "Yeniden Yurtlanma Sürecinde Suriyeli Mülteciler: Türkiye'nin Göç Mevzuatının Toplumsal Cinsiyet Bağlamında İncelenmesi”, Uluslararası İnsan Çalışmaları Dergisi, 1(2), s. 365-373. doi: 10.35235/uicd.467015.

Hajj, H. (2016) "The Syrian Musicians in Istanbul: The Relationship Between Repertoire and Stage", Alternatif Politika, $8(3)$, s. 474-487.

Kızıltepe, Z. (2017). İçerik Analizi. Nitel Araştırma Yöntem, Teknik, Analiz ve Yaklaşımlar. Seggie, F. N.,Bayyurt, Y. (Ed.). Anı Yayıncılık, Ankara.

Polat, Y. (2017), Türkiye'de Suriyeli Göçmenlerin Entegrasyonu Bağlamında Üniversite Eğitimi Sorunsalı, H. Özdemir (Haz.), Turgut Özal Uluslararası Ekonomi ve Siyaset Kongresi IV Küresel Siyasette Yeni Yönelimler Bildiriler Kitabi.

Poyraz, Y. (2012) "Suriye Vatandaşlarının Geçici Korunması ve Uluslararası Mülteci Hukuku”, Selçuk Üniversitesi Hukuk Fakültesi Dergisi, 20(2), s. 55-69. doi: 10.15337/SUHFD.2017.65.

Sencer, M., ve Irmak, Y. (1984) Toplum Bilimlerinde Yöntem, Say Yayınları, İstanbul.

Ulusu Karataş, ve A. E. (2020) “Geçici Koruma Altındaki Suriye Vatandaşlarının Çocuk Yaşta Evliliklerinin Mukayeseli Hukuka ve Türk Hukukuna Göre Geçerliliği”, İstanbul Hukuk Mecmuası, 78 (1), s. 21-81.

https://www.goc.gov.tr/gecici-koruma5638. (Erişim Tarihi: 5 Haziran 2021). 